\title{
Constitutional Bounds of Database Protection: The Role of Judicial Review IN THE CREATION AND DEFINITION OF PRIVATE RIGHTS IN INFORMATION
}

\author{
By Yochai Benkler ${ }^{\dagger}$
}

\begin{abstract}
The article analyzes the constitutional bounds within which Congress is empowered to regulate the production and exchange of information by creating private rights. As a test case for answering this question, it analyzes the differences between two radically different bills for protecting database providers, reported in late September of 1999 by two committees of the House of Representatives. One bill, House Bill 354, is unconstitutional. The other, House Bill 1858, probably is constitutional. The article suggests that the Intellectual Property Clause and the First Amendment create two layers of judicial review over acts of Congress that recognize exclusive private rights in information. It suggests that judges have an important role to play as a counterweight to political processes in which the value of the public domain to future generations and to users is systematically underrepresented.
\end{abstract}

\section{TABLE OF CONTENTS}

I. INTRODUCTION

II. ThE LAw: Two Constitutional Constraints ON Private Rights IN INFORMATION

A. Constraints in the Intellectual Property Clause ...........................................539

1. The Substantive Constraints Imposed by the Intellectual Property Clause

2. Congress's Power to Create a Different Kind of Right Under the Commerce Clause...

B. Of Black Beauty and Blackacre: The First Amendment and Property in Information

C. Conclusion: Two Constitutional Constraints

III. THE REASON: Why AdOPt RoBUSt JUdicial REVIEW OF PRIVATE RightS IN INFORMATION?

(C) 2000 Yochai Benkler.

$\dagger$ Associate Professor of Law, New York University School of Law. My thanks to Alex Driggs for outstanding research assistance. The research and writing of this article were supported by a grant from the Filomen D'Agostino and Max E. Greenberg Research Fund of the New York University School of Law. 
A. The Centrality of Free Information Flows to Democracy and Autonomy .....558

B. "Progress" and the Political Economy of Enclosure...................................569

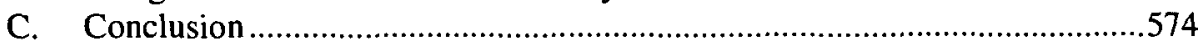

IV. Constitutionaltiy of the Database Protection Bills under the

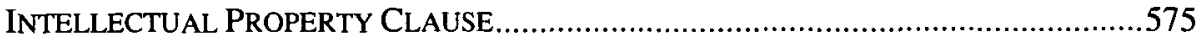

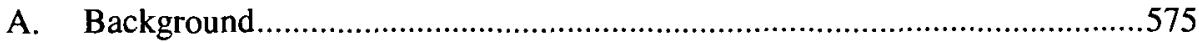

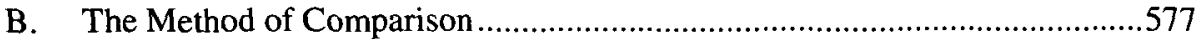

C. A Functional Comparison of House Bill 354 and House Bill 1858_.............578

1. Whom Does the Law Address? .....................................................578

2. What is Prohibited to the Law's Addressees? ...................................580

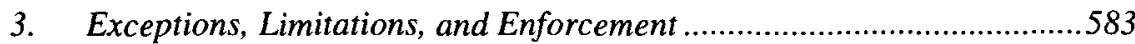

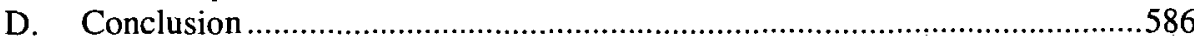

V. Constitutionaltity of the Database Protection Bills UNDER THE FiRST

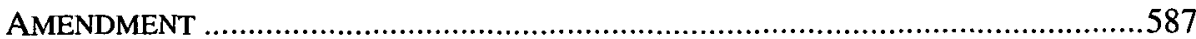

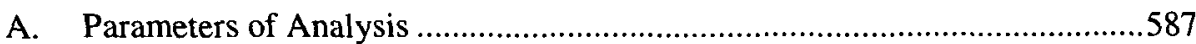

B. Identifying and Evaluating the Goals of Database Protection ........................589

C. Evaluating the Fit Between the Means Employed by the Bills and their

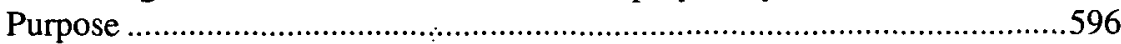

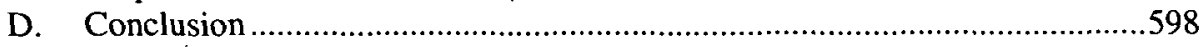

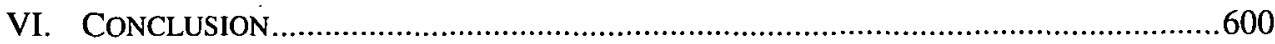

\section{INTRODUCTION}

Imagine Congress enacted a law that stated:

(1) Whoever publishes a news report, weather report, historical or scientific article, or other statement of fact, shall have an exclusive right to the use of the facts incorporated in that report and not previously publicly reported elsewhere.

(2) For a period of fifteen years following initial publication, no person may publish or distribute in interstate commerce facts subject to the exclusive right defined in paragraph (1) without the permission of the owner of the facts.

So Matt Drudge gets to say who may, and who may not, report on the Lewinsky affair. CNN and Time get to say who reports about the existence-or non-existence-of Operation Tailwind.

What prevents Congress from enacting such a law? Is it only prudence and the good judgment of its members? Are there constitutional constraints on congressional creation of exclusive private rights in information? If so, what are they?

The answer is that there are two cumulative constitutional constraints that prevent enclosure of the public domain so extensive as to be detrimental to our information environment. First, the Intellectual Property Clause imposes a set of threshold constraints on when it is that Congress may say that one person, and no other, may control this information, this knowl- 
edge, this piece of our common culture. ${ }^{1}$ Second, the First Amendment adds another layer of judicial oversight, to assure that even legislation that meets the threshold conditions, or is exempt from them because it can properly be passed under another power, does not impose too heavy a burden on our capacity to access information and communicate to others as autonomous individuals and as constituents of a democratic society. ${ }^{2}$

The question of constitutional constraints on Congress's power to enclose the public domain is of immediate practical import. The past few years have seen an upsurge in enclosure legislation, as those who stand to gain from stronger property rights drive their fences deeper into the heart of our information environment, staking out ever-larger holdings. ${ }^{3}$ Of most immediate concern here are the database protection bills that have been introduced in Congress over the past few years. The stark differences between the iterations of this effort currently before the House of Representatives-House Bill 354, reported from the Committee on the Judiciary by Representative Coble, creating a property right in raw information in

1. See Malla Pollack, The Right to Know?: Delimiting Database Protection at the Juncture of the Commerce Clause, the Intellectual Property Clause and the First Amendment, 17 CARDOZO ARTS \& ENT. L.J. 47, $50-54$ (1999); Malla Pollack, Unconstitutional Incontestability?: The Intersection of the Intellectual Property and Commerce Clauses of the Constitution: Beyond a Critique of Shakespeare Co. v. Silstar Corp., 18 SEATTLE U. L. REV. 259, 260 (1995); Theodore H. Davis, Jr., Copying in the Shadow of the Constitution: The Rational Limits of Trade Dress Protection, 80 MINN. L. REV. 595, 596 (1996); David L. Lange, The Intellectual Property Clause in Contemporary Trademark Law: An Appreciation of Two Recent Essays and Some Thoughts About Why We Ought to Care, 59 LAW \& CONTEMP. PROBS. 213, 232 (1996); Julie Cohen, Copyright and the Jurisprudence of Self-Help, 13 BERKELEY TECH. L.J. 1089, 1130-35 (1998).

2. For older commentaries raising this concern, see generally Melville B. Nimmer, Does Copyright Abridge the First Amendment Guaranties of Free Speech and the Press? 17 UCLA L. REV. 1180, 1181-86 (1970); Paul Goldstein, Copyright and the First Amendment, 70 ColuM. L. REV. 983, 984 (1970); Robert C. Denicola, Copyright and Free Speech: Constitutional Limitations on the Protection of Expression, 67 CAL. L. REV. 283, 284 (1979). In the 1990s, these concerns were again raised. See generally Diane Leenheer Zimmerman, Information as Speech, Information as Goods: Some Thoughts on Marketplaces and the Bill of Rights, 33 WM. \& MARY L. REV. 665 (1992); L. Ray Patterson \& Stanley F. Birch, Jr., Copyright and Free Speech Rights, 4 J. INTELL. PROP. L. 1 (1997); Mark A. Lemley \& Eugene Volokh, Freedom of Speech and Injunctions in Intellectual Property Cases, 48 DUKE L.J. 147 (1998). I have provided my own treatment of these issues in Yochai Benkler, Free As the Air to Common Use, First Amendment Constraints on Enclosure of the Public Domain, 74 N.Y.U. L. REV. 354 (1999).

3. See, e.g., Sonny Bono Copyright Term Extension Act, Pub. L. 105-298, 112 Stat. 2827 (1998); Digital Millennium Copyright Act, Pub. L. 105-304, 112 Stat. 2860 (1998); see also James Boyle, Sold Out, N.Y. TIMES, Mar. 31, 1996, § 4, at 15; Pamela Samuelson, The Copyright Grab, WIRED, Jan. 1996, at 134-35. 
all but name, and House Bill 1858, reported from the Committee on Commerce by Representative Bliley, that assiduously avoids creating a property right-bring to the fore both a specific and a general constitutional question. The specific question is, what are the constitutional bounds on Congress's power to delineate property rights in facts and in compilations of facts. This article will seek to answer this question by analyzing these dueling bills. The more general question is, what are the constitutional parameters that constrain the power of Congress to regulate the production and exchange of information and knowledge through the creation of exclusive private rights. I will answer this more general question first, to frame my analysis of the database bills.

Three constitutional reference points set the parameters of the answers to both the specific and the general questions. These are the Intellectual Property Clause, ${ }^{4}$ the First Amendment speech clause, and Congress's near-plenary power under twentieth century interpretations of the Commerce Clause. There are three basic points to understand about these parameters.

First, the Intellectual Property Clause, at least since the Trade-Mark Cases in $1879,{ }^{5}$ has been understood to be not only an empowering clause, but also one that limits to what extent and in what manner Congress can secure exclusive rights in information. Second, the reasons for the limitation in that clause reflect a substantive concern that Congress should not create exclusive rights in information and knowledge unless these rights fall within the constraints imposed by the Intellectual Property Clause. While congressional powers usually need not be mutually exclusive, this is not the case when Congress is engaged in creating private rights to control the production and exchange of information in society. Rather, Congress cannot use a power other than the Intellectual Property Clausemost importantly, its power to regulate interstate commerce-to enact ex-

4. U.S. CONST. art. $1, \S 8, \mathrm{cl} .8$. The anachronistic name ("intellectual property" was not a term known to the Framers) more accurately describes the scope of the clause than the more technical term sometimes used "the patents and copyrights clause," and is more useful for contemporary purposes than the more historically and descriptively accurate "exclusive rights of authors and inventors clause." See Edward C. Walterscheid, Inherent or Created Rights: Early Views on the Intellectual Property Clause, 19 HAMLINE L. REV. 81, 81 (1995). The term has been used for at least 15 years to denote this power. See, e.g., Robert W. Kastenmeier \& Michael J. Remington, The Semiconductor Chip Protection Act of 1984: A Swamp or Firm Ground?, 70 MINN. L. REV. 417, 441 (1985) ("The argument that a particular interest group will make more money and therefore be more creative does not satisfy ... the constitutional requirements of the intellectual property clause.").

5. Trade-Mark Cases, 100 U.S. 82 (1879). 
clusive rights inconsistent with the substantive constraints imposed by that clause. Third, the Intellectual Property Clause and the First Amendment interact to contain Congress's powers to regulate the flow of information in our information environment. Cumulatively, they seek to assure that no one will capture the legislative process to privatize that most precious of all public domains-our knowledge of the world that surrounds us. That public domain is germane to our ability to decide for ourselves and talk to each other about how we ought to live our lives as individuals and as members of a community.

Part $\Pi$ explains the constraints that the Intellectual Property Clause and the First Amendment impose on legislation that creates exclusive private rights in information. Part III explains why one would want a robust system of judicial review of such legislation, in terms of the centrality of free information flows to democracy and autonomy, and in terms of the political economy of legislative creation of exclusive rights in information. Part IV analyzes the pending database bills in terms of the Intellectual Property Clause, and finds House Bill 354, but not House Bill 1858, unconstitutional. A careful analysis of the provisions of House Bill 354 suggests that it is functionally an intellectual property right in data. Under the Supreme Court's interpretation of the Intellectual Property Clause, Congress lacks the power to enact such a right. Part $V$ analyzes the two bills in terms of the First Amendment, and again finds the former bill deficient and the latter bill more defensible. There is no serious evidence that a right of the type created in House Bill 354 is necessary to further a significant public purpose. Furthermore, there is reason to believe that it would burden valuable speech too much for too speculative a gain in database production.

\section{THE LAW: TWO CONSTITUTIONAL CONSTRAINTS ON PRIVATE RIGHTS IN INFORMATION}

\section{A. Constraints in the Intellectual Property Clause}

In 1879, the Supreme Court was posed with the following question: can Congress enact a trademark protection statute? In $1870^{6}$ and $1876^{7}$ Congress had passed statutes providing for registration and enforcement of trademarks. The Trade-Mark Cases involved three prosecutions under the latter statute, and the Court considered whether Congress had the power to enact these laws. Relying on the statutory language, the Court first deter-

6. Act of July 8,1870 ch. $230 \S \S 77-84,16$ Stat. 198 (entitled "An Act to Revise, Consolidate, and Amend the Statutes Relating to Patents and Copyrights").

7. Act of Aug. 14, 1876, 19 Stat. 141. 
mined that Congress had purported to act under the Intellectual Property Clause, not the Commerce Clause of Article $\mathrm{I}^{8}$ Then the Court held that Congress could not, consistent with Article I, Section 8, clause 8 protect trademarks because trademarks lacked the originality that is the sine qua non of protection under that clause. ${ }^{9}$ It expressly reserved the question of the appropriateness of regulating trademarks under the Commerce Clause, which indeed later became the source of authority for the Lanham Act. ${ }^{10}$

It is important to focus on what the Court did and did not do in the Trade-Mark Cases. The Court did hold that the Intellectual Property Clause is not an open-ended grant of power to Congress to create exclusive rights in information, but a specifically limited grant available only to protect original contributions to the wealth of human knowledge. This limitation on the appropriate subject matter for property rights in information is constitutionally embedded, and is germane to the power of Congress to act in this field. But the Court did not, at least in these cases, state that the limitations in the Intellectual Property Clause applied to all congressional attempts to recognize exclusive rights in information.

From a contemporary perspective, the Trade-Mark Cases establish the important principle that the Intellectual Property Clause constrains congressional power, and that it is the proper role of judges to step in and tell Congress when its zeal to enact property rights exceeds its power to do so under the Constitution. The cases also establish the principle that originality is a threshold requirement before information can become the object of exclusive rights under the Intellectual Property Clause.

8. See 100 U.S. at 93.

9. The Court explained:

The ordinary trade-mark has no necessary relation to invention or discovery. The trade-mark recognized by the common law is generally the growth of a considerable period of use, rather than a sudden invention. ... The writings which are to be protected [under this clause] are the fruits of intellectual labor, embodied in the form of books .... While such [trade-mark protection] legislation may be a judicious aid to the common law on the subject of trade-marks, and may be within the competency of legislatures whose general powers embrace that class of subjects, we are unable to see any such power in the constitutional provision concerning authors and inventors, and their writings and discoveries.

Id. at 94 .

10. Act of July 5, 1946, ch. 540, 60 Stat. 427 (1946) (codified as amended at 15 U.S.C. $\S \S 1051-1127$ (1994)). 
These basic principles have since been upheld systematically by unanimous or near-unanimous Supreme Court opinions. ${ }^{11}$ Two clusters of opinions - in the 1960s, and later in the late 1980s and early 1990sdeveloped and more clearly articulated the substantive constraints imposed by the Intellectual Property Clause on Congress's power to legislate exclusive rights in information. These cases offer a robust defense of the importance of the public domain to the "Progress of Science and the Useful Arts," and evidence an equally robust commitment by the Court to treat the Intellectual Property Clause as a structural constraint on Congress's power to enclose the public domain.

\section{The Substantive Constraints Imposed by the Intellectual Property Clause}

The first cluster of opinions involves direct statements by the Courtspeaking unanimously-about the constraints imposed by the constitutional provision itself. In 1966 the Court interpreted the nonobviousness requirement for patentability in Graham v. John Deere Co. ${ }^{12}$ The Court explained that the clause "is both a grant of power and a limitation." ${ }^{13}$ In clear language, which it has reaffirmed since, ${ }^{14}$ the Court stated that "Congress in the exercise of the patent power may not overreach the restraints imposed by the stated constitutional purpose." 15 Specifically, the Court held that the Intellectual Property Clause requires that Congress (a) act only when extending an exclusive right promotes "[i]nnovation, advancement, and ... add[s] to the sum of useful knowledge" ${ }^{\text {"16 }}$ and (b) not recognize exclusive rights "whose effects are to remove existent knowledge from the public domain, or to restrict free access to materials already available." 17 The Court reasoned that this unusual express limitation on the power granted in the same clause is a reflection of its framers' aversion to a system of government grants of monopolies in trade-a strategy used by the Crown to reward its favorites. ${ }^{18}$

11. See Feist Publications, Inc. v. Rural Tel. Serv. Co., Inc., 499 U.S. 340, 346-47 (1991); Bonito Boats, Inc. v. Thunder Craft Boats, Inc., 489 U.S. 141, 146 (1989); Sears, Roebuck \& Co. v. Stiffel Co., 376 U.S. 225, 230 -31 (1964); Compco Corp. v. Day-Brite Lighting, Inc., 376 U.S. 234, 237-38 (1964).

12. 383 U.S. 1 (1966). See also discussion infra Part II.A.1.

13. Id. at 5 .

14. See, e.g., Bonito Boats, 489 U.S. at 146.

15. 383 U.S. at 5-6.

16. Id. at 6 .

17. Id.

18. See id. at 5. Cf. Sears, Roebuck \& Co. v. Stiffel Co., 376 U.S. 225, 229-30 (1964) (comparing patent grants under American and English systems). On the aversion 
Explaining why patents fall within the conceptual ambit of disfavored "monopolies" rather than the presumably beneficial category of "property," the Court referred to the writings of Thomas Jefferson, who as Secretary of State was one of the first to implement the patent system under the Patent Act of $1790 .{ }^{19}$ Jefferson was initially skeptical about the advisability of empowering Congress to provide for patents at all, ${ }^{20}$ but he later accepted their utility within bounds. ${ }^{21}$ His skepticism is most clearly reflected in a letter to Isaac McPherson, quoted at length by the Court in Graham. ${ }^{22}$ Here Jefferson presented not a generalized abhorrence for monopoly, but a very specific sophistication about information as a good.

to monopolies, and how it resonated in the thinking of the drafters of the Constitution about patents, see Edward C. Walterscheid, To Promote the Progress of Science and the Useful Arts: The Background and Origin of the Intellectual Property Clause of the United States Constitution, 2 J. INTELL. PROP. L. 1, 37-38 (1994).

19. The Court's description of Jefferson's role in the development of patent law has been criticized on historical grounds. See generally Edward C. Walterscheid, The Use and Abuse of History: The Supreme Court's Interpretation of Thomas Jefferson's Influence on the Patent Law, 39 IDEA 195 (1999).

20. See 383 U.S. at 7-8 (citing letter to Madison dated July 1788 arguing that "the benefit even of limited monopolies is too doubtful to be opposed to that of their general suppression").

21. See id. at 8 (citing letters to Madison and Oliver Evans).

22. The Court quoted Jefferson as follows:

Stable ownership is the gift of social law, and is given late in the progress of society. It would be curious then, if an idea, the fugitive fermentation of an individual brain, could, of natural right, be claimed in exclusive and stable property. If nature has made any one thing less susceptible than all others of exclusive property, it is the action of the thinking power called an idea, which an individual may exclusively possess as long as he keeps it to himself; but the moment it is divulged, it forces itself into the possession of every one, and the receiver cannot dispossess himself of it. Its peculiar character, too, is that no one possesses the less, because every other possesses the whole of it. He who receives an idea from me, receives instruction himself without lessening mine; as he who lights his taper at mine, receives light without darkening me. That ideas should freely spread from one to another over the globe, for the moral and mutual instruction of man, and improvement of his condition, seems to have been peculiarly and benevolently designed by nature, when she made them, like fire, expansible over all space, without lessening their density in any point, and like the air in which we breathe, move, and have our physical being, incapable of confinement or exclusive appropriation. Inventions then cannot, in nature, be a subject of property. Society may give an exclusive right to the profits arising from them, as an encouragement to men to pursue ideas which may produce utility, but this may or may not be done, according 
Poetic though his language may be, Jefferson's reasoning is entirely comprehensible and irresistible to the economically literate late twentieth century commentator. Information is a public good. It is nonexcludable and nonrival. ${ }^{23}$ Its nonexcludability makes it unsusceptible to appropriation, except by grant of exclusive right coupled with the threat of state enforcement; consequently, this characteristic is the potential justification for recognizing and enforcing such rights. But because information is also purely nonrival, the social cost of its use by many people, once it is produced, is zero. It is therefore desirable that information be at least partially nonexcludable, because that attribute permits free access to information by those who value it at its social cost-the value of their attention to it-but not enough to pay a positive price above that social cost. Unlike land, or cows, then, information does not lend itself to the simple assumption of the presumptive beneficial effect of treating it as the subject of property. The free exchange of information, rather than its enclosure, is the presumed beneficial state, and enclosures of information are thus like sometimes-necessary "monopolies," rather than normally-beneficial "property."

The upshot of the Court's interpretation of the Intellectual Property Clause in Graham is that the clause expressly constrains the power of Congress to create exclusive rights in information. This limitation is based on substantive reservations that those who drafted the Constitution had towards granting anyone exclusive rights to use and benefit from information and knowledge. That the limitation reflects a substantive concern and

to the will and convenience of the society, without claim or complaint from anybody.

Id. at $8 \mathrm{n} .2$.

23. Every economic good can be defined by the degree to which it is excludable, and the degree to which it is rivalrous. A good is excludable to the extent that its producer can appropriate its benefits by excluding those who benefit from it unless they pay a price. A good is rivalrous to the extent that its use by one person prevents (rivals) its use by another person. The former is a function of the available technology for exclusion, and the institutional (legal) framework that permits or facilitates such technically feasible exclusion. The latter is purely "technological." It is an attribute of the good itself-it either can, or cannot, as a practical matter, be used by many people without degradation or rivalry. A pure private good is one that is excludable and rivalrous. A pure public good is one that is nonexcludable and nonrivalrous. When a good is public in the sense of being nonexcludable, it is so because no firm can capture its social value. It must therefore be provided publicly, if at all. By definition, a nonrivalrous good is one that can be used by one person without preventing or degrading its use by any other person. Any additional person who uses the good imposes no social cost. Its optimal demand price is therefore zero. At that price, however, it would not be produced by private interests, and must be provided publicly. At a higher price, which would induce private production, it will be under-consumed, and hence under-produced. 
not a formality is important. It suggests that it should apply to laws purportedly passed under powers granted to Congress outside of the clause itself. Otherwise, simple legislative drafting contrary to the constraints imposed by the Intellectual Property Clause, enacted under a different power, could too easily undermine the substantive commitments animating the constraint. Furthermore, the constraint is not primarily the textually obvious "for limited times" requirement. Rather, it is the requirement that exclusive rights in information actually can promote the Progress of science and the useful arts; there must be at least a plausible claim that a given right can actually increase information production. ${ }^{24}$ The clause also requires that Congress recognize exclusive rights only in exchange for adding to the wealth of public knowledge, and that it not grant rights that have the effect of removing information already available in the public domain. ${ }^{25}$

A quarter of a century later, the Court again revisited the constitutional constraints imposed on Congress by the Intellectual Property Clause, this time in the context of copyright. In Feist, a unanimous Court ${ }^{26}$ held that Congress cannot, consistent with the Intellectual Property Clause, constitutionally recognize exclusive private rights in raw facts. "Originality," stated the Court, "is a constitutionally-mandated prerequisite for copyright

24. Perhaps the most intellectually indefensible recent extension of exclusive rights in these terms is the Sonny Bono Copyright Term Extension Act, Pub. L. No. 105-298, 112 Stat. 2827 (1998). The law extends the term of copyright by twenty years, retroactively as well as prospectively. For example, the term for works owned by corporations was extended from 75 to 95 years. To suggest that such a law can create incentives to creators of copyrightable materials requires a belief that there will be some work, somewhere, that will not be produced unless it is secured a royalty stream in years 76 to 95 . One would do well to be skeptical of any artist or executive who claims that the decision whether or not to produce a given information product will be affected, however marginally, by expectations regarding the revenue stream in years 76 to 95 . To suggest that retroactive application of such an extension would create an incentive requires belief in an even more preposterous claim that authors would decide to produce something that would not recoup their costs within the copyright period secured to them at the time they make the decision to produce, but they will nonetheless produce it if they expect that future extensions of copyright term will be retroactively applied to their works. Without regard to any of these concerns, a federal district court for the District of Columbia upheld the term extension act against, among other claims, the claim that it offends the "limited times" constraint of the Intellectual Property Clause. See Eldred v. Reno, 74 F. Supp. 2d 1, 6-7 (D.C. Cir. 1999).

25. See 383 U.S. at 5-6, 8-9.

26. See Feist Publications, Inc. v. Rural Tel. Serv. Co., 499 U.S. 340, 351 (1991). Justice Blackmun concurred in the judgment, but without writing his reservations from joining the opinion. 
protection."27 Relying on the Trade-Mark Cases, the Court made amply clear that facts could not constitutionally be made the subject of copyright protection. ${ }^{28}$ The Court relied on the concept that facts preexist their statement by a human agent; being the first to articulate a set of facts does not make that person the facts' originator. ${ }^{29}$ And only originators, or in the terms of Graham, only those who add to human knowledge, may receive an exclusive right in what they added. ${ }^{30}$ This, in turn, is understood by the Court to create a constitutionally mandated framework not only to assure authors rights in their original expressions, but also to "encourage[] others to build freely upon the ideas and information conveyed by the work." 31 As with Graham, the concern is substantive, not formal. It is a concern, treated as going to the very heart of the constitutional constraint, that Congress not enclose existing information and facts by granting exclusive rights. Three years later, in another unanimous opinion, Campbell v. AcuffRose Music, Inc., the Court reiterated its position in Feist, and implied that not only originality, but some form of "fair use" constraint on the scope of intellectual property is implicit in the constitutional constraint itself. ${ }^{32}$

Although Feist is couched in terms of "copyright," it would be implausible to claim that the Court could have based its decision so heavily on the constitutionally protected status of public access to facts and information, but expected that the exact same exclusive rights that it invalidated could be enacted simply by inserting in the preamble words to the effect that the Commerce Clause, not the Intellectual Property Clause, is the source of power upon which Congress relies. The Intellectual Property Clause speaks of "exclusive rights," not of the technical terms-well known to its drafters —of "patents" or "copyrights." It grants and restricts Congress's power to grant such exclusive rights. And the Court has repeatedly, and unanimously, stated that this constraint requires originality as a precondition to the availability of an exclusive right, and that it prevents Congress from creating exclusive rights in information that is already in the public domain-like facts, whether stated or not. Limitations are rare in Article I, Section 8 grants of congressional power-bankruptcy

27. Id. at 351 .

28. See id. at 362 .

29. See id. at $347-48$.

30. See id. at 345-46.

31. Id. at 349-50.

32. See 510 U.S. 569, 575 (1994); see also Feist Publications, Inc. v. Rural Tel. Serv. Co., 499 U.S. 340, 359 (1991) ("facts contained in existing works may be freely copied"); Harper \& Row, Publishers, Inc. v. Nation Enters., 471 U.S. 539, 547 (1985) (copyright owner's rights exclude facts and ideas, and fair use). 
laws must be nationally uniform, ${ }^{33}$ an army can only be funded for two years. ${ }^{34}$ As others, like Jane Ginsburg, ${ }^{35}$ Malla Pollack, ${ }^{36}$ Theodore Davis, ${ }^{37}$ and William Patry, ${ }^{38}$ have exhaustively explained, Congress may no more enact an exclusive right in information that conflicts with the limitations imposed by the Intellectual Property Clause than it may fund an army for three or four years using the general spending power, or aid the employees of a single railroad by enacting special provisions for the distribution of the assets of their employer. ${ }^{39}$ To paraphrase Chief Justice Rehnquist on Congress's attempt to circumvent the uniformity requirement of the Bankruptcy Clause, "to hold otherwise would allow Congress to repeal the [originality] requirement from Art. I, $\S 8, \mathrm{cl}$. [8], of the Constitution., 40

United States v. Moghadam ${ }^{41}$ is the only case directly to address an Intellectual Property Clause challenge to congressional legislation sought to be justified under the Commerce Clause. In Moghadam, the United States Court of Appeals for the Eleventh Circuit upheld the anti-bootlegging statute, which prohibits unauthorized recordings of live musical performances. ${ }^{42}$ The defendant challenged the constitutionality of the statute by arguing that Congress may only give authors and inventors rights to their "writings," medium, it is not "a writing." 44 The court held that whether or not legislation under the Intellectual Property Clause could only apply to works fixed in a tangible medium, the anti-bootlegging statute was valid under the

33. See U.S. CONST. art. I, § 8, cl. 4. In Railway Labor Executives' Ass'n. v. Gibbons, 455 U.S. $457,468-69$ (1982), the Court struck down an attempt by Congress to circumvent this limitation.

34. See U.S. ConST. art. I, \& 8, cl. 12.

35. See Jane Ginsburg, No "Sweat"? Copyright and Other Protection of Works of Information After Feist v. Rural Telephone, 92 COLUM. L. REV. 338, 369-74 (1992).

36. See Pollack, supra note 1.

37. See Davis, supra note 1.

38. See William Patry, The Enumerated Powers Doctrine and Intellectual Property: An Imminent Constitutional Collision, 67 GEO. WASH. L. REV. 359, 367-68 (1999).

39. But see Ginsburg, supra note 35 , at $374-85$ (arguing that Congressional findings regarding the scope of terms within the Intellectual Property Clause should receive extreme judicial deference).

40. See Railway Labor Executives' Ass'n v. Gibbons, 455 U.S. 457, 473 (1982) ("To hold otherwise would allow Congress to repeal the uniformity requirement from Art. I, $\S 8$, cl. 4 , of the Constitution.").

41. 175 F.3d 1269 (11th Cir. 1999).

42. See 175 F.3d at 1282 (upholding 18 U.S.C. $\$ 2319$ A).

43. U.S. CONST. art. $1, \S 8$, cl. 8.

44. See 175 F.3d at 1274 . 
Commerce Clause. ${ }^{45}$ At first glance, the case seems to fly in the face of the analysis in the preceding paragraph. On closer inspection, however, it does not.

The court in Moghadam clearly accepted the general relationship between the Intellectual Property Clause and the Commerce Clause, interpreting Railway Labor Executives to mean that there are "circumstances ... in which the Commerce Clause cannot be used by Congress to eradicate a limitation placed upon Congress in another grant of power." ${ }^{46}$ The court's holding suggests that it interposed a quite reasonable gloss on this relationship-that only important or central constraints created by the Intellectual Property Clause, and not merely technical constraints, displace Congress's power under other clauses of Article I, Section 8 of the Constitution. The anti-bootlegging statute deviated, according to the court, merely from the fixation requirement implied by the word "writings" in the Intellectual Property Clause, and that requirement is not so central to the Intellectual Property Clause as to negate a commerce clause-based law that gives copyright-like rights in live performances. ${ }^{47}$ Significantly, the court partly justified its holding by stating that an exclusive right to record live musical performances does cohere with the requirement of originality, ${ }^{48}$ which was presumably more important in the court's eyes. It also expressly stated that its holding "is limited to the fixation requirement, and should not be taken as authority that the other various limitations in the Copyright Clause can be avoided by reference to the Commerce Clause.",49

Whether the case was correctly decided ${ }^{50}$ is less important than that the court recognized Congress's power to create intellectual property-like

45. See id.

46. See id. at 1280.

47. See id. at 1281 .

48. See id. at 1280 .

49. Id. at $1281 \mathrm{n} .14$.

50. It is not entirely clear that the court was correct in its view that the fixation requirement is a technical constraint, rather than one that is central to the scheme of securing incentives and assuring access that is the design principle of the Intellectual Property Clause. Copyright has generally relied on the fixed medium as a rough balancing point between incentives and access. Rights to the fixed medium secure the incentives, and the porous boundaries of the medium permit some free access to the information, which is the economically efficient price at which information should be available once it is produced. The fixation requirement can therefore be seen as a historically contingent, but nonetheless central, constraint of the Intellectual Property Clause to assure that the law does not eliminate important points at which information can spill over into the public domain. If the fixation requirement is in fact so understood, then under the Moghadam court's own understanding of the relationship between the Intellectual Property Clause and the Commerce Clause, the anti-bootlegging statute would be unconstitutional. More- 
rights under the Commerce Clause only if they do not negate the substantive constraints imposed by the Intellectual Property Clause on the enactment of such rights. Feist excludes the possibility that an exclusive right to information in a database could be treated as conflicting with the Intellectual Property Clause in merely a technical sense. Graham, Feist, and Acuff-Rose similarly foreclose an interpretation that would permit exclusive rights that more generally circumvent the originality requirement or enclose materials in the public domain to be passed under the Commerce Clause.

\section{Congress's Power to Create a Different Kind of Right Under the Commerce Clause}

What power does Congress nonetheless have to regulate information markets after the possibility of using exclusive rights is removed? We know from the Trade-Mark Cases that the commerce power permits Congress to regulate certain uses of information beyond the scope of the Intellectual Property Clause - the Lanham Act is a case in point. What are the boundaries of this power, and how does it relate to the constraints imposed by the Intellectual Property Clause? These questions are answered, albeit indirectly, in a second cluster of opinions concerning the constitutional bounds imposed by the Intellectual Property Clause on state laws that are inconsistent with federal intellectual property laws. These opinions are one step removed from the question of direct constraints the Intellectual Property Clause places on Congress, because they involve the respective powers of the states and the federal Constitution. Nonetheless, in the course of working out to what extent the states are bound by the constraints imposed by the Intellectual Property Clause, the Court further articulated and strengthened the basic propositions set out from the Trade-Mark Cases to Graham and Feist. Namely, the Intellectual Property Clause imposes a constraint on what exclusive rights in information Congress can legislate.

over, economically, a performance, unlike the music when fixed in most tangible media, is perfectly excludable-the artist can keep anyone out of the auditorium or the stadium unless they pay. The incentive to perform therefore can be completely captured by contract-tickets at the gate. This excludability also permits the artists to roll into the ticket price lost sales of music on fixed media caused by displacement by bootlegs. So the economic justification of the bootlegging statute is questionable. The statute provides an obvious boon to record labels, which get a much higher portion of the revenue on fixed media sales, but the displacement effect on artists, who receive a high percentage of the revenue on performances but a low one on sales of fixed media, is minimal. The antibootlegging statute therefore seems to challenge the Intellectual Property Clause's clear solicitude for authors, not publishers, as the objects of its protection. Performing a full analysis of the importance of the fixation requirement is, however, beyond the scope of this article and, as stated in the text, unnecessary to evaluate the database legislation. 
And the Court also outlined the types of information exchange regulations that would be justified under the Commerce Clause without running afoul of the substantive constraints created by the Intellectual Property Clause.

In 1964 the Court considered whether state unfair competition law could be used to create a general, property-like entitlement for unpatented or unpatentable designs. In Sears, Roebuck \& Co. v. Stiffel Co. ${ }^{51}$ and Compco Corp. v. Day-Brite Lighting, Inc., ${ }^{52}$ the Court interpreted the holdings below to have been "based wholly on the fact that selling an article which is an exact copy of another unpatented article is likely to produce and did in this case produce confusion as to the source of the article." 53 Because the Court saw these cases as equating confusion with copying, it interpreted them as creating, de facto, an alternative propertylike right against copying of unpatented designs, rather than a contextually applied prohibition on causing market confusion. Such a right, in turn, "would interfere with the federal policy, found in Art. I, $\S 8, \mathrm{cl} .8$, of the Constitution and in the implementing federal statutes of allowing free access to copy whatever the federal patent and copyright laws leave in the public domain." ${ }^{54}$ The Court specifically limited its holding, stating that it did not exclude the possibility of state regulation of unfair trade practices, like preventing palming off by regulating labeling. ${ }^{55}$ But these laws could not be used in such a manner as effectively to negate the basic constitutional mandate that a design that is "in the public domain . . . can be copied in every detail by whoever pleases. $" 56$ The emphasis on this limitation of the constitutional constraint on unfair competition law-that states retain the power to regulate "specifically oriented predatory business practices"- was the basis of Justice Harlan's concurrence. ${ }^{57}$

The Sears and Compco cases came under pressure for, and eventually were abandoned with respect to, their preemptive effect on states. In $\mathrm{Bo}$ nito Boats, Inc. v. Thunder Craft Boats, Inc., ${ }^{58}$ the Court expressly abandoned the proposition that the Intellectual Property Clause directly prevented the states from "adopt[ing] rules for the promotion of intellectual

51. 376 U.S. 225 (1964).

52. 376 U.S. 234 (1964).

53. Id. at 237.

54. Id.

55. See id. at 238.

56. Id.

57. Id. at 239.

58. 489 U.S. 141 (1989). 
creation within their own jurisdictions. ${ }^{, 59}$ But in that same case the Court reiterated and revitalized the core holding of Sears and Compco, namely that states could not provide rights that offered patent-like protection, but undermined "the ultimate goal of public disclosure and use which is the centerpiece of federal patent policy." ${ }^{60}$ In Bonito Boats the Court considered a Florida statute, purportedly concerned with unfair competition, that prohibited use of the most efficient method of copying the design of a boat hull-using an existing boat to create a mold, and then using the mold to create boats that copy the original hull design. ${ }^{61}$ The statute protected hull designs whether they were patentable or not. ${ }^{62}$ In this case, the manufacturer had not applied for a patent prior to marketing the boat and the hull design could therefore no longer be patented. ${ }^{63}$ The Court suggested that nothing prevented a state from passing a real unfair competition law, one concerned with "the protection of consumers, not the protection of producers as an incentive to product innovation." ${ }^{64}$ The Florida statute was not that type of law. Rather,

[i]n contrast to the operation of unfair competition law, the Florida statute is aimed directly at preventing the exploitation of the design and utilitarian conceptions embodied in the product itself.... To accomplish this goal, the Florida statute endows the original boat hull manufacturer with rights against the world, similar in scope and operation to the rights accorded a federal patentee. $^{65}$

Giver the functional similarity between the protection offered by the Florida statute to unpatented, and unpatentable designs and patent protection, the Court held that the statute was preempted. ${ }^{66}$

59. Id. at 165 (citing Aronson v. Quick Point Pencil Co., 440 U.S. 257, 262 (1979); Goldstein v. California, 412 U.S. 546, 552-61 (1973); and Kewanee Oil Co. v. Bicron Corp., 416 U.S. $470,478-79$ (1974)).

60. Bonito Boats, 489 U.S. at 157.

61. See id. at 144-45.

62. See id. at 158-59.

63. See id. at $144-45,159$.

64. Id. at 157 ("[T]he plaintiff has the right not to lose his customers through false representations that those are his wares which in fact are not, but he may not monopolize any design or pattern, however trifling. The defendant, on the other hand, may copy plaintiff's goods slavishly down to the minutest detail: but he may not represent himself as the plaintiff in their sale." (quoting Judge Learned Hand in Crescent Tool Co. v. Kilborn \& Bishop Co., 247 F. 299, 301 (2d Cir. 1917))).

65. Bonito Boats, 489 U.S at 158.

66. Some have suggested that Bonito Boats could be read as a retreat from the longstanding position that the Intellectual Property Clause imposes real limitations on Con- 
In conjunction, the Graham-Feist and Sears-Compco-Bonito Boats lines of cases suggest that the Intellectual Property Clause imposes a threshold constraint on congressional legislation that regulates information production and exchange. Congress may not create rights that are functionally the type of exclusive right that it is empowered to create under the Intellectual Property Clause, except in compliance with that clause's limitations. Under the clause, Congress may create such rights if and when they are likely to encourage information production more than they inhibit it, if it makes them available only to those who make original contributions to the wealth of our collective knowledge, and if the exclusive right enacted does not remove, or burden free access to, information already in the public domain. While Congress may regulate information markets under the Commerce Clause as well, it may do so only to the extent that it does not thereby circumvent the limitations placed by the Intellectual Property Clause on its power to create exclusive rights. As Ginsburg ex-

gress's power. See Pollack, supra note 1, at 64-66. The argument relies on the Court's heavy focus on the congressional definition of the contours of patent policy, coupled with its express abandonment of a notion of direct preemptive effect of the Intellectual Property Clause on state legislation, and its conclusion that "[i]t is for Congress to determine if the present system of design and utility patents is ineffectual in promoting the useful arts in the context of industrial design." Bonito Boats, 489 U.S. at 168. This would, however, be a misreading of Bonito Boats. The case involved the question of direct preemption, reviewing a state court decision that found state law to be preempted by the federal statute, not directly by the Intellectual Property Clause of the Constitution. See id. at 141 . The Court began with an express reiteration, described in the text, of its long-standing position on the express limitations imposed by the Clause, and then went on to describe the history of congressional patent legislation as implementing the policies embedded in the constitutional constraints. See id. The Court's holding was that Congress had the role, in the first instance, to determine how best to fulfill the purpose of the Intellectual Property Clause, and if Congress, acting within its constitutional mandate, left an area of possible private rights in information free for state experimentation, then courts should not take it upon themselves to review each piece of state law for direct preemption by the Intellectual Property Clause. See id. at 168. This scheme leaves the Intellectual Property Clause as the final arbiter of the propriety of private rights in information, but it operates at the level of challenging congressional law. Valid congressional law, in turn, provides the framework against which state law must be measured. This leaves the question open as to whether courts can act in direct application of the clause in response to systematic overreaching by states and in the absence of congressional legislation, or whether a challenge must be fashioned to the reigning federal intellectual property law that leaves an area improperly unpreempted. But that was not the question in Bonito Boats. There, the Court only held that it was Congress's responsibility, in the first instance, to determine what state laws must be preempted so as not to interfere with the policies embedded in the Intellectual Property Clause. See id. at 165. The Court also reiterated that Congress's decisions themselves were in fact subject to judicially-enforceable interpretation of the requirements of that clause. See id. at 162-63. 
plained in her criticism of Feist, this limitation requires that regulations enacted under the commerce power be different in kind, not only in subject matter and degree, from the exclusive property-like rights that are the subject of the Intellectual Property Clause. ${ }^{67}$ This difference in kind, which is nowhere more clearly articulated than in the Court's explanation in Bonito Boats of the differences between acceptable consumer protection-like regulation and unacceptable quasi-property rights. ${ }^{68}$ But when the substantive content and function of the right created by Congress crosses over the line of property-like protection (as some might argue it does in the case of the Federal Trademark Dilution Act of 1995) ${ }^{69}$ Congress's actions stand on constitutional quicksand.

Even though a right in information can be constitutionally passed under the Intellectual Property Clause or the Commerce Clause, it may nonetheless involve a restriction on speech that renders it suspect under the First Amendment. This restriction arises because the enforcement of rights in information and cultural products always involves the state in refraining one person or another from using information or communicating in a manner that that person wishes to and could, but for the intervention of a law enforcement officer. The more context-sensitive judicial review that follows from this simple observation is discussed in the following section.

\section{B. Of Black Beauty and Blackacre: The First Amendment and Property in Information}

In 1970, Melville Nimmer wrote about the difference between recognizing exclusive rights in the proverbial Blackacre and recognizing similar rights in a novel like Black Beauty. The difference, he wrote, lay in the First Amendment. ${ }^{70}$ A good number of other commentators have since written about the inherent conflict between exclusive rights in information and the promise that "Congress shall make no law abridging the freedom of speech." ${ }^{, 71}$

67. See Ginsburg, supra note 35 , at $374-84$.

68. Bonito Boats, 489 U.S. at 157-59.

69. See Robert C. Denicola, Freedom to Copy, 108 YALE L.J. 1661, 1665-67 (1999).

70. See Nimmer, supra note 2, at 1193 ("If I may own Blackacre in perpetuity, why not also Black Beauty? The answer lies in the first amendment. There is no countervailing speech interest which must be balanced against perpetual ownership of tangible real and personal property. There is such a speech interest with respect to literary property, or copyright.").

71. See generally sources cited supra note 2; Julie E. Cohen, A Right to Read Anonymously: A Closer Look at "Copyright Management" in Cyberspace, 28 ConN. L. REV. 981, 1020-21 (1996). 
The basic conflict is analytically simple. A property right in an information good is created only if Congress prohibits most people from using certain information in certain ways. For example, in order for former President Ford to have a property right in the contents of his memoirs, the law must, at the end of the day, empower the sheriff to come to the door of The Nation magazine and confiscate its copies, or collect a fine, for writing an article that includes in it too many words that are copied from the Ford memoirs. ${ }^{72}$ Whenever the law permits the sheriff to walk into people's offices and confiscate their publications, or levy against their belongings because of something they said or how they said it, the First Amendment is deeply implicated. ${ }^{73}$

The Nation's quotation from the Ford memoirs was presented to the Supreme Court in Harper \& Row. In that case, the Court held that in the context of copyright, the conflict between property rights and the First Amendment was false, because "the Framers intended copyright itself to be the engine of free expression. By establishing a marketable right to the use of one's expression, copyright supplies the economic incentive to create and disseminate ideas." statement should not be viewed as excluding First Amendment review of the actual contours of copyright law. The Court only resolved the conflict by reference to internal copyright doctrines that are increasingly under pressure-like fair use or the idea/fact-expression dichotomy implicated by the database laws. ${ }^{75}$ Here, I only briefly restate that argument.

First, standard economic understandings of the incentives created by intellectual property suggest that some degree of copyright protection will increase incentives of information producers over time. However, if producers have too complete a set of rights in their information products overall production over time will decline, because the increased costs that future producers must pay to present producers for using their products as inputs will exceed the value of expected returns to present producers. Therefore, Harper \& Row should at the very least be read to mean that a properly-tailored copyright scheme is an engine of free expression, leaving room for at least some First Amendment review of the contours of

72. See Harper \& Row, Publishers, Inc., v. Nation Enters., 471 U.S. 539 (1985).

73. For a more complete statement of this issue, see Benkler, supra note 2 , at 38694.

74. 471 U.S. at 558.

75. See generally Benkler, supra note 2, at 394-412; Yochai Benkler, A Political Economy of the Public Domain: Markets in Information Goods vs. The Marketplace of Ideas, in EXPANDING THE BOUNDS OF INTELlECTUAL PROPERTY: INNOVATION POLICY FOR THE KNOWLEDGE SOCIETY (R. Dreyfuss et al. eds., forthcoming 2000). 
copyright law, such as whether it includes a sufficiently robust fair use provision. ${ }^{76}$

Moreover, I have elsewhere explained why intellectual property rights prefer large-scale, commercial producers that integrate information production with management of owned information inputs over professional and amateur noncommercial producers, and to a lesser extent over smallscale commercial authors and inventors who do not own an inventory of information goods. ${ }^{77}$ This is so because the preferred organizations gain from increases in rights in a way that organizations that do not sell access to their products do not, and because they can better absorb the downstream input-cost-increase effects of intellectual property by reutilizing their own inventory. ${ }^{78}$ If this is in fact the case, then copyright is "the engine of free expression" for some, but not others. It is the engine for Disney, but a drag on the Electronic Freedom Foundation or on the Free Republic Forum, for instance. ${ }^{79}$ Since copyright provides incentives only to certain kinds of producers who have a limited set of reasons to put pen to paper, but imposes costs on many other types of writers, it is only in a very circumscribed form that it can in fact be "the engine of free expression;" it must leave enough room for political and cultural creation that is not driven by direct sales. ${ }^{80}$

But one need not revisit and revise, or even clarify Harper \& Row to see that the First Amendment imposes distinctive constraints on the regulation of information production and exchange, both when the regulation falls within the Intellectual Property Clause, and most certainly when it falls outside of it.

[C]opyright's idea/expression dichotomy [strikes] a definitional balance between the First Amendment and the Copyright Act by

76. See Benkler, supra note 2, at 395-96.

77. Yochai Benkler, Intellectual Property and the Organization of Information Production 31-35 (1999), available at 〈http://www.law.nyu.edu/benklery//pec.PDF〉(PDF file).

78. It is standard that intellectual property rights have the dynamic effect of increasing input costs for all future information producers. My point is that producers who own large inventories can reutilize owned inventory as inputs, and thereby reduce the cost increases that an expansion of intellectual property rights is usually thought to create. All others suffer the full impact of the increase in rights. See generally id. at 29-39.

79. The Free Republic forum is a web-based political discussion forum, whose participants cut and paste stories from newspapers they read online, and use these stories to start discussion threads about the story. The site operator was sued by the Washington Post and the Los Angeles Times in 1998. For a more complete description, see Benkler, supra note 2.

80. See id. at 394-412. 
permitting free communication of facts while still protecting an author's expression. ... No author may copyright his ideas or the facts he narrates.... As this Court long ago observed: "[The] news element-the information respecting current events contained in the literary production-is not the creation of the writer, but is a report of matters that ordinarily are publici juris; it is the history of the day. ${ }^{, 81}$

It is this fact about copyright law that causes the Court to refuse to recognize The Nation's claim in Harper \& Row. The Court's refusal comes "[i]n view of the First Amendment protections already embodied in the Copyright Act's distinction between copyrightable expression and uncopyrightable facts and ideas, and the latitude for scholarship and comment traditionally afforded by fair use. ..."82 Copyright scholars ${ }^{83}$ have often and forcefully reiterated that copyright can live in harmony with the First Amendment if copyright law provides enough breathing space in the public domain for writers and speakers to rely on the work of their predecessors, in particular for their ideas, the facts they report, and for transformative uses at the very heart of the fair use doctrine. ${ }^{84}$

The analysis that applies to the Copyright Act is suggestive of the relationship between the First Amendment and the Intellectual Property Clause. The constraints on laws imposed by the Intellectual Property Clause - the originality requirement, the exclusion of materials already in the public domain, and the express time limitation-are inherent constraints on the tension between property rights in information enacted within the confines of that clause, and the values of free speech. It is not, however, impossible that laws will meet the threshold constraints of the Intellectual Property Clause, but will in context fail the more contextsensitive First Amendment review that must be applied to all content-

81. Harper \& Row, Publishers, Inc., v. Nation Enters., 471 U.S. 539, 556 (1985) (alteration in original) (citations omitted).

82. Id. at 560 .

83. See Jessica Litman, Copyright Owners' Rights and Users' Privileges on the Internet: Reforming Information Law in Copyright's Image, 22 DAYTON L. REV. 587, 619 (1997) ("[T]he harmony between the First Amendment and copyright doesn't inhere in their essential nature; rather, it derives from accommodations and restrictions we have built into copyright to enhance its role as an engine of free expression."); see also Lemley \& Volokh, supra note 2, at 210-16 (developing a remedy scheme for copyright that better comports with the First Amendment); Lange, supra note 1, at 240; David Lange, At Play in the Fields of the Word: Copyright and the Construction of Authorship in the PostLiterate Millennium, 55 LAW \& CONTEMP. PROBS. 139, 140-44 (1992) (copyright grew out of government censorship efforts). "[W]hat comes naturally to copyright . . . is the deliberate, if selective, suppression and advancement of speech." Id. at 142.

84. See Campbell v. Acuff-Rose, 510 U.S. 569, 579 (1994). 
neutral ${ }^{85}$ direct regulations of speech. Any rule that says to one person: "you cannot say $x y z$ without the permission of $a$, and if you say $x y z$ without such permission the sheriff will come knocking at your door" must, at the very least, be shown actually to serve a very important state interest, and must not burden more speech than necessary. ${ }^{86}$ This is so even if Congress is acting out of the best of intentions to improve the flow of information in society, as has been seen in at least some media regulation cases. One might easily imagine a court finding that applying an extension of the term of copyright by twenty years to new works does not run afoul of the "limited times" constraint in the Intellectual Property Clause, ${ }^{87}$ but nonetheless imposes a very real restraint on too much valuable speech in return for "too speculative a gain." $" 88$

This care, due in evaluating regulations of information production and exchange enacted under the Intellectual Property Clause, is doubly necessary when considering such regulations that cannot be enacted constitutionally within the bounds imposed by that clause. In the absence of the constraints that require originality, solicitude to the public domain, consis-

85. Lemley \& Volokh argue that copyright laws are content-based, because it is impossible to tell which speech is permissible and which is not without reference to the specific content of a message. See Lemley \& Volokh, supra note 2, at 186. For example, saying "Romeo, oh Romeo," is not prohibited, but singing "when you're a Jet you're a Jet" is. And the reason is the content of the statement. While attractive, I am unsure whether this view construes too literally the Court's rationale for exercising the next-tohighest scrutiny for content-based regulation, as compared to content-neutral laws on the one hand, and viewpoint-based on the other. As the Court has repeatedly stated, whether a law is content-based or content-neutral goes to the purpose of the legislature-was the law justified in terms irrespective of the content of the speech? See Rosenberger v. Rector and Visitors of the Univ. of Virginia, 515 U.S. 819, 828-29 (1995); Madsen v. Women's Health Center, Inc., 512 U.S. 753, 763 (1994); Ward v. Rock Against Racism, 491 U.S. 781,791 (1989). In the case of copyright, and intellectual property more generally, it seems that the law is more like media regulation than like any other law-a law that specifically regulates the production and exchange of information, and thus is always suspect, but nonetheless a law whose purpose is the promotion of speech generally, not of one particular speech determined by content. Here I will continue, as I have done before, to assume that general information-control rules are content-neutral, not content-based. Needless to say, if the Lemley \& Volokh position is adopted, the laws I criticize here are on even shakier grounds than I have already suggested.

86. See, e.g., Turner Broad. Sys., Inc. v. FCC, 520 U.S. 180, 189 (1997); Denver Area Educ. Telecomms. Consortium, Inc. v. FCC, 518 U.S. 727, 741 (1996); Turner Broad. Sys., Inc. v. FCC, 512 U.S. 622, 662 (1994).

87. A claim raised in the plaintiff's papers in Eldred v. Reno, 74 F. Supp. 2d 1, 6-7 (D.C. Cir. 1999). See Plaintiff's Response to the Government's Motion for Judgment on the Pleadings and Cross-Motion for Summary Judgment, 25-29, available at 〈http://cyber.law.harvard.edu/eldredvreno/sj_memo.pdf .

88. See 518 U.S. at 760. 
tent availability of information and ideas for use by the public, and time limitation, the First Amendment becomes a more important backstop against regulation that restricts information flow too much for too speculative a gain.

\section{Conclusion: Two Constitutional Constraints}

The upshot of the analysis is that a law that assigns to some people rights to prevent others from accessing certain information, or communicating in certain ways, must comply with two constitutional constraints.

First, if the nature of the right is an exclusive right intended to create market incentives for its owners, or protect those owners' investments, by permitting them to exclude others from making valuable uses of the information, then Congress may act only within the confines of the Intellectual Property Clause. It may only give such rights in original works. It cannot create such rights as would enclose or burden access to information or knowledge already available to the public, and it cannot give exclusive rights to control ideas or facts. Furthermore, Congress may only enact rights under other clauses of Article I, Section 8, in particular the Commerce Clause, if these rights are different in kind from the rights that it is empowered, within constitutional bounds, to create under the Intellectual Property Clause. Creating a general right, good against the world, in "the news of the day," for example, is beyond the power of Congress.

Second, private rights to control the use of information, whether created within the confines of the Intellectual Property Clause or properly created outside of that framework, are regulations on speech. As such, they are subject to independent and cumulative review under the First Amendment. Because of the clause's solicitude towards the freedom of the public to use the same information in which it grants limited exclusive rights, this review will usually-though not always-result in permitting regulations that pass muster under a robust application of the clause. However, when Congress creates a right outside the bounds of the Intellectual Property Clause, free of the limitations inherent in that clause, First Amendment review must become a more robust constraint. Before applying these constraints to the pending database protection bills, however, one must first consider what might justify such an elaborate two-tier constitutional limitation on legislation of private rights in information. 


\section{THE REASON: WHY ADOPT ROBUST JUDICIAL REVIEW OF PRIVATE RIGHTS IN INFORMATION?}

Why would anyone want to erect such cumbersome constitutional hurdles to enacting private rights in information products? The answers fall into two broad categories. First, free information flows are central to freedom-both in the sense of personal autonomy, and in the sense of political or democratic self-governance. Policies that block off various flows of information, or maldistribute access to and control over our information environment, affect all of our abilities - both as individuals and as members of communities - to be self-governing. Constitutionally based judicial review is most valuable to prevent the implementation of policies that exert these kinds of costs on individual autonomy and the proper functioning of democratic processes.

Second, the production of information, knowledge, and culture, is a conversation over time and space among creative human beings, one whose impediment will fundamentally challenge our welfare as a society and a culture. This centrality is expressed in the constitutional concern with "Progress," and requires robust institutional constraints to prevent present generations from appropriating too much of this grand conversation at the expense of participants from future generations.

Grafted over this somewhat romantic concept of "Progress" is the hard-nosed realization that the politics of private rights in information involve a systematic imbalance between the private stakes for those who benefit from them and for those who suffer their costs. The social gains of private rights are perceivable as private gains by their beneficiaries. These beneficiaries therefore fully represent in the political process the value of the benefit. But the social losses caused by such rights are diffused among all potential users of the information and therefore no one knows the full scope of these costs. In particular, these losses are borne by future generations that cannot be represented in present political processes, and thus, the costs of expanded property rights in information are systematically under-represented. The result is that legislatures suffer from structural rosy vision when they consider creating private rights in information, and judges must step in to re-evaluate laws passed using this skewed perspective when the costs become apparent enough to a party to a suit.

\section{A. The Centrality of Free Information Flows to Democracy and Autonomy}

Why should laws regulating information and communications markets be subject to more extensive judicial review than laws regulating grain or securities markets? After all, one might say, it is one thing to have very 
close scrutiny of government when it attempts to censor individual expression or public discourse, but what has that got to do with review of normal market-creating and market-regulating functions that the state has always filled ${ }^{89}$

The answer that has co-evolved with First Amendment law in the twentieth century ${ }^{90}$ has been that markets in information affect democracy and autonomy in ways that suggest an important role for courts, whereas other markets affect welfare in ways that do not similarly call for close judicial scrutiny, at least not under the federal Constitution. One can look anywhere from Madison ${ }^{91}$ to Brandeis ${ }^{92}$ for inspiration and will meet a similar set of conceptual commitments. For a community to be democratically self-governing its members must have access to information, this information must not be too tightly controlled by one group or another, and constituents must be able to express their views as well as receive information. ${ }^{93}$ These commitments are most urgently engaged when the government purposefully tries to regulate debate in order to assure that the message it prefers will prevail in the public arena. But the extremity of the concern in those situations need not obscure the fact that the same set of commitments is engaged when the government regulates information exchange among members of society for reasons that are understood by lawmakers to be information flow neutral, or even to support the free flow

89. It does not matter much to this article whether one is more or less attached to the notion that since the New Deal there has been more regulatory activity, and we have moved from a pure market economy to a mixed economy, or whether one understands property law and contract law, replacing, say, guilds and royal monopolies, as similarly involving government regulation of production and exchange.

90. See generally David M. Rabban, Free Speech in Progressive Social Thought, 74 TEX. L. REV. 951 (1996); 2 ZECHARIAH CHAFEE, GOVERNMENT AND MASS COMMUNICATIONS 471-719 (1947) (in particular pages 678-719).

91. This is by reference to Madison's oft quoted statement that "[a] popular Government, without popular information, or the means of acquiring it, is but a Prologue to a Farce or a Tragedy; or, perhaps both. Knowledge will forever govern ignorance: And a people who mean to be their own Governors, must arm themselves with the power which knowledge gives." 9 WRITINGS OF JAMES MADISON 103 (G. Hunt ed., 1910).

92. See, e.g., Whitney v. California, 274 U.S. 357, 374-78 (1927) (Brandeis, J., concurring).

93. For a superb and comprehensive consideration of the relationship between varying conceptions of democratic self-governance and the information policy preferences they generate, see generally C. Edwin Baker, The Media the Citizen Needs, 147 U. PA. L. REV. 317 (1998). The literature developing various versions and perceptions includes CHAFEE, supra note 90; Owen Fiss, Why the State?, 100 HARV. L. REV. 781 (1987); Cass SunsteIn, Democracy AND THE Problem of FreE SPEech (1993); and Jack Balkin, Frontiers of Legal Thought II The New First Amendment: Some Realism About Pluralism: Legal Realist Approaches to the First Amendment, 1990 DUKE L.J. 375. 
of information. ${ }^{94}$ If a law "gets it wrong" in the area of information flow regulation, it has negative effects on democracy that in the United States we have chosen to treat as particularly amenable to judicial oversight. ${ }^{95}$

I have elsewhere retold stories that illustrate this effect of seemingly neutral intellectual property rules on democratic discourse-for example, how the scientologists used copyright to quash a critic, ${ }^{96}$ or how the Washington Post and the Los Angeles Times sought to prevent readers from sharing copies of articles online in order to stimulate political discourse. ${ }^{97}$ Another little appreciated example of this effect, particularly pertinent to the object of our analysis here-exclusive rights in facts, history, the news of the day-is the Supreme Court's decision in International News Service $v$. Associated Press. ${ }^{98}$ The case seemed to revolve around a question of whether the Associated Press ("AP") had a limited property-like right in the news its correspondents collected, at least vis-à-vis its competitor wire service of the time, the International New Service ("INS"). As the facts were presented in the case, INS reporters would take the facts published on the East Coast by AP-associated papers, and wire them to the West Coast, where its affiliated papers published simultaneously with, or even ahead of, AP affiliated papers. ${ }^{99}$ Over the objections of Justices Holmes and Brandeis, the Court declared that the AP did in fact have a quasiproperty right in the information ${ }^{100}$ - a holding whose remnants still occupy the very bills that are the subject of analysis in this article. ${ }^{101}$

My point here is not, however, to revisit the wisdom or necessity of the "hot news" exception to the general wisdom that facts are not properly the subject of intellectual property. My point, rather, is to illustrate how an intellectual property rule can influence democratic discourse. The dispute

94. See generally Benkler, supra note 2, at 364-81.

95. The claim about the special role of courts in protecting speech as opposed to other rights is historically and culturally contingent. As many other nations and some states in the United States show, there is nothing incoherent about a state recognizing social and economic rights as similarly appropriate for judicial review. On the development of positive rights under state constitution see Helen Hershkoff, Positive Rights and State Constitutions: The Limits of Federal Rationality Review, 112 HARV. L. REV. 1131, 1154 (1999).

96. See Religious Tech. Ctr. v. Netcom On-Line Communications Servs., Inc., 923 F. Supp. 1231, 1238-40 (1995). For a description, see Benkler, supra note 2, at 356.

97. See supra note 79 (describing Free Republic case).

98. 248 U.S. 215 (1918).

99. See id. at 231 .

100. See id. at 240.

101. See, e.g., H.R. 1858, 106th Cong. \& 201 (1999). 
revolved around news reports from World War I. ${ }^{102}$ AP served Pulitzer papers, and its bylaws allowed Pulitzer to exclude Hearst papers from receiving the AP wires. ${ }^{103}$ The INS was formed as a news service to serve those newspapers excluded from AP - namely, the Hearst papers. During the war, the European Allies excluded INS correspondents from receiving news or using transatlantic cables because the Hearst papers generally espoused an anti-English or anti-Allied position. The effect of the Court's market-regulatory decision to exclude INS papers from using AP's hot news was to burden newspapers that espoused a certain position in a hotly contested political issue in the United States. There is no evidence to suggest that the decision was based on a substantive preference for one set of political views or another rather than on the considerations of fairness and efficiency upon which the Court relied. But the point of this story is not to suggest that the Court improperly tweaked intellectual property law to support its members' views. The point is that, like many other courts when they don their "intellectual property" hats, the Court was blind to the effects of its decision about property rights on democratic discourse. Recognizing a property right in the news of the day made it possible for those who espoused one view of a central political question of the time to control public reporting and debate of that question. It is a particularly clear instance of the general effect of property rights in information; they affect not only, or even primarily, how much information is exchanged in our public conversations, but more importantly who gets to say what to whom, and who decides these questions.

A less commonly recognized effect of property rights in information is that they create a similar set of concerns for our normative commitment to personal autonomy. The point has to do with the degree of control that individuals have over the information environment from within which they make their life choices, and the degree of control others have to shape the information environment within which an individual chooses. To be an autonomous individual is to be, to a significant extent, the author of one's life through a series of successive choices. To choose our path in the world, we must have a sense of the range of options open to us and an evaluation of the relative worth of these options. These two elements of information-knowledge of options for action and an evaluative framework to compare them-are germane to our capacity to be the authors of our lives. The pattern of distribution in a society of control over the infor-

102. For historical accounts of the case, from which the following discussion is drawn, see HAROLD INNIS, THE BIAS OF COMMUNICATION 179-80 (1991); see also Epstein, INS v. AP: Custom and Law, 78 VA. L. REV. 85, 90-93 (1992).

103. See 248 U.S. at 264 n.1 (Brandeis, J. dissenting). 
mation that defines the range of options open to individuals in that society is central to the extent and distribution of autonomy in that society. ${ }^{104}$ Property in information is one dimension of information law that can give some people control over the information environment of others, which they can use to alter the likelihood that those others will behave in a manner conducive to the plans of those who own the information. When this happens, property rights increase the ability of their owners to author the lives of others, and decrease the autonomy of those others.

Imagine that Jane wants to buy a home, having settled into a new job. Her job leaves her very little time to shop for a mortgage during times when the two banks in her town are open. Given her personal condition, her search costs are high so she only knows about mortgage rates available from these two banks. ${ }^{105}$ She soothes her concern over not having time to search for a better mortgage by assuming that the market is efficient, and that all banks offer roughly equal terms. It turns out, however, that the mortgage rates of the two banks are higher than those available in larger urban areas in the state, reflecting the fact that there are many people in town who share Jane's predicament. At the mortgage rate available from either of these two banks Jane cannot afford a house-she must live in an apartment. At the mortgage rate available from banks at larger urban centers, she could afford a house. But she does not know of this choice. Given her state of knowledge, the only choice she sees as open to her is what apartment to live in, not whether to live in an apartment or a house. Assume that is a decision important enough to one's well-being to count as a choice, the presence or absence of which can plausibly be seen as important to one's personal autonomy. ${ }^{106}$

Now bring in property rights. Along comes a database company that plans to collect data from the lists of mortgages compiled and maintained

104. For more complete statements of this point, see Benkler, supra note 2; see also Yochai Benkler, Siren Songs and Amish Children: Autonomy, Information, and Law (Feb. 10, 2000) (unpublished manuscript, on file with author).

105. Search costs are a form of transaction cost that describes the cost a party must incur to search for its most desired good. As search costs increase, a party will settle for a lower fit between the good she has and what her first best preference would have been in the absence of costs, and accept a good that is as close to that preference but that can be identified with search costs that are lower than the difference between the value of the preferred good to the party and the value of the good actually acquired.

106. See JOSEPH RAZ, THE MORALTY OF FREEDOM 375 (1986) (describing the need for a range of choices at many layers of importance - from the mundane to the grand-to make a life self-authored, or autonomous); see also Margaret Jane Radin, Residential Rent Control, 15 PHIl. \& PUB. AFF. 350 (1988) (describing centrality of home to personhood). 
by all the banks in the state, and compiles them into a single, easily accessible database. ${ }^{107}$ Assume that, were such a database available to consumers, Jane would have the time and money to buy it and use it to expand her knowledge of available mortgages, and with it her known set of options. The company's business plan forecasts acceptable returns, assuming the present state of the law on ownership of facts-they are in the public domain, free as the air to common use. As it turns out, Congress passes a law that gives the banks a property right in the facts of their compilation, so the database producer cannot copy them into a larger, value-added database without permission. ${ }^{108}$ It turns out that there are many banks in this state like the two banks in our town. These banks are quite happy to deny access to their data, or to charge a price that would compensate them for the premiums (over competitive rates) that they would lose from consumers like Jane. Faced with these new, higher costs of creating its database (paying for each bank's list rather than simply searching for and copying the lists), the database company abandons its project.

One common response to such a story would be to view it as a simple example of the well-known static efficiency losses caused by intellectual property rights, which, if justified, are usually justified by their beneficial incentive effects on dynamic efficiency. An information product that would have been produced is not produced, even though its value will exceed the marginal cost of its production. ${ }^{109}$ What I would like to focus on, however, is the effect of this decision on Jane's choice set and on the distribution of power to control the definition of her choice set.

In the absence of the property right, the banks had no formal right to limit Jane's perception of the life choices open to her. Jane's perception was limited by her life conditions and the choices of others around her, but not by a legal right that prevented a change in that perception. When the banks' property rights were recognized, they received a legal right to prevent such a change, to prevent use of their information to change her knowledge of her options. By denying access to their information, a denial similarly exercised by other banks operating under similar circumstances,

107. The example of mortgage lists and their compilation in the manner described in the text is taken from the Committee Report on House Bill 1858 as an example of what its narrow scope is intended to exclude. See H.R. REP. NO. 106-350, pt. 1, at 8 (1999)

108. This is in fact what House Bill 354 proposes to do. See H.R. REP. No. 106-349, pt. 1 , at 9 (1999).

109. Note here that the marginal cost of information, once produced, is zero, and that the marginal social cost of use of the mortgage price lists that banks generate for internal purposes is similarly zero. The increased cost reflects the private cost to the banks of losing control over their information, but not a social cost. See id. at 10-12. 
the banks imposed their preferred picture of the world on Jane, limiting her perception of her life choices so as to increase the likelihood that she will behave in a manner conducive to their interests. The banks did not care whether Jane lived in an apartment or a house. But they did want Jane to buy her mortgage from them, at a high price, and they are now entitled to prevent access to their information so as to affect Jane's choice. As a by-product of increasing the likelihood that Jane will act in a manner consistent with their plans, they restricted Jane's life options so that she now may only choose from among apartments, but not between being an apartment-dweller and a homeowner.

Imagine another alternative: that the database compiler did invest in collecting the information, relying precisely on the new property right to justify the investment. This is, after all, the beneficial incentive effect sought for the law. Assume further, however, that the costs of collection are such that only one or two companies can undertake them, given the expected market for the information itself. One of two things will happen. Either the first database compiler will sell the aggregate information to consumers like Jane, or it will sell to small town banks its agreement to abstain from selling the information. ${ }^{110}$ The banks have better information about the value of the information in the database than do those consumers who should value it most highly-namely, those who, in the absence of the database, do not know about lower mortgages. But these are precisely the consumers least able to determine the value to them of access to this database. So, the company will or will not release the information, based on whether these consumers as an aggregate under- or overestimate the premium they are paying for not knowing what other mortgages are available. Competing database compilers would be warded off from entering the market to serve consumers, however, even if the first database compiler did not sell to consumers. They would expect that once they enter the market, small town banks will no longer value (and pay for) withholding the information, and the first database compiler would have to turn to consumers to appropriate the value of its investment. That provider will then be able to price below the new entrant, because it has already recouped some or all of its compilation costs from the banks, whereas the new entrant has to recoup these costs entirely from consumers.

110. Imagine that the agreement is part of the terms of sale of the initial access to the bank's database. The bank might require, for example, that the data only be available to consumers in certain organizations, so as not to undermine the bank's advantage vis-à-vis most consumers, or that the information be included only in databases of loans available in small towns. 
Recognizing property rights in information created a locus of control that allowed various players in a social environment to try to manipulate the information environment of others in that society so as to affect their behavior. When property rights are designed in ways that have a more-orless predictable effect of centralizing control over information, or systematically tipping the scales in favor of one group or another in controlling the information environment of some other group, our normative concerns with autonomy ought to be engaged.

This effect of property in information is under-recognized. Indeed, the concern with autonomy is usually cited in opposition to policy recommendations to restrict property in information, which themselves are usually defended in the name of democracy or robust political discourse. The most explicit instance of this perception of the conflict is the debate between Owen Fiss and Robert Post. ${ }^{111}$ The theory underlying both these commentators' acceptance of the conflict between democracy and autonomy as ways of approaching information law is their joint acceptance of autonomy as a sphere of noninterference by the state, ${ }^{112}$ not as a personal condition admitting of degree, whose extent and pattern ought to be the concern of information law and policy.

A review of some central liberal accounts of autonomy, ${ }^{113}$ however, suggests that personal autonomy is best understood both as a threshold, on/off category-which would justify treating autonomy as inconsistent

111. See, e.g., OWEN M. FISS, LIBERALISM DIVIDED: FREEDOM OF SPEECH AND THE MANY USES OF STATE POWER 36-38 (1996); Robert Post, Equality and Autonomy in First Amendment Jurisprudence, Reviewing Fiss, Liberalism Divided, 95 MICH. L. REV. 1517 (1997).

112. To be clear, I am not implying that Post's sophisticated critique takes on a simplistic libertarian conception of autonomy. But he does suggest that managerial control over life choices undermines the very concept of autonomy, and hence the value depends on abstention from managing the extent of and capacity for autonomy that people actually have. Since, he argues, a concern for democracy must derive from a concern for individual autonomy, he rejects the notion that autonomy and democracy collide, proposing instead that autonomy and equality collide. This conflict, and his overarching commitment to autonomy, lead to his acceptance of only very limited regulations, on clearly defined entities such as broadcast outlets designated as public functionaries, within a framework that generally rejects benign regulation in aid of either a robust system of public discourse or of better information flows necessary for autonomous choice. See Post, supra note 111, at 1538-39. See generally Robert Post, Meiklejohn's Mistake: Individual Autonomy and the Reform of Public Discourse, 64 U. COLO. L. REV. 1109 (1993) (providing a critique of supposedly democracy-based regulations that undermine autonomy, and the ascriptive conception of autonomy upon which his analysis relies).

113. I rely for this account primarily on Joel Feinberg, Autonomy, in THE INNER CITADEL 27 (J. Christman, ed., 1989); GeRALD DWORKIN, THE THEORY AND PRACTICE OF AUTONOMY (1988); JOSEPH RAZ, THE MORALTTY OF FREEDOM 369-99 (1986). 
with constraints on property rights - and as a matter of degree-which would justify paying close attention to the actual effects of property rights in information on personal autonomy. Both aspects of the concept are normatively significant. ${ }^{114}$ Thinking of autonomy as a threshold capacity to be self-governing, which almost all sane adults have, animates the liberal attention to treating all individuals as self-governing and deserving as such of equal regard. On this conception alone, autonomy calls for abstaining more than for designing an environment within which people can be more autonomous. Thinking of the degree to which individuals can exercise this capacity as normatively relevant alters one's policy focus. For, if the capacity of individuals to be autonomous while living in a world largely made by others and the amount of autonomy they actually possess, are a matter of degree, and if the degree of autonomy available to individuals should be seen as a normative concern of that society, then increasing people's autonomy becomes an important concern for policy making.

The argument about information policy and autonomy goes more or less like this. Individuals can have more or less capacity to lead autonomous lives, and their lives can be, as a factual matter, more or less autonomously lived, based on the extent to which they can play a role in authoring their own lives. The quantum of autonomy people can have and do actually enjoy is partly a function of the information they have about the world as it is, and the options open to them to live their lives. This information, central to individual autonomy, can in turn be more or less controlled by the individual. Information policy that moves the center of control over the information environment from within which each of us must choose and live our lives, in turn, affects the extent to which we can be, and are, autonomous. As law permits individuals to play a more significant part in defining the information environment from within which they choose their lives, it enhances the relative role those individuals play in authoring their own lives. As it does so, it can be seen as a more autonomy-loving law. As law shifts control over the information environment from within which its subjects choose away from most individuals, it undermines the personal autonomy of most of its subjects. Courts, acting as institutional defenders of individual rights, are the appropriate locus to protect personal autonomy from information laws that shift control over

114. On the difference and its importance between ascribing only threshold capacity for autonomy as opposed to describing quanta of autonomy as normatively relevant, see Richard H. Fallon, Jr., Two Senses of Autonomy, 46 STAN. L. REV. 875 (1994). 
individuals' information environment away from them-whatever the supposed beneficial effects of the shift in terms of the general welfare. ${ }^{115}$

The hypothetical example of Jane's mortgage focused on direct control over access to information relevant to defining the options open to one person. One finds more murky, but still instructive, examples in actual cases.

Consider the question of how intellectual property interacts with perceptions of matter so central to self-definition as sex and sexuality. At the most basic level we see the case in which the United States Olympic Commission used its statutory exclusive right over the use of the term "Olympic" to obtain a court order preventing organizers of the "Gay Olympic Games" from using this term to name their event. ${ }^{116}$ The Court understood the case before it as concerned with a right to commercial exploitation. But, as Boyle has explained, ${ }^{117}$ this commercial right was used in that case for private censorship-to prevent the expression of a cultural message about the acceptability of homosexuality as a way of living. While no one could plausibly claim that this decision eliminated homosexuality from the range of options known to be open to individuals defining their sexuality, it is a rather crisp instance of exclusive property rights intervening in determining who has the power to control public statements about the relative worth of this life choice as opposed to alternative life choices. ${ }^{118}$

At a more "technologically sophisticated" level, we might see two suits brought by Playboy Enterprises to try to control the social meaning of the alphanumeric string, "playboy." In one case a former playmate, Terri Welles, used the term in the metatags describing her site to search

115. Identifying the information policies that support both individual autonomy and robust democratic discourse is a fascinating project that must be left for another day.

116. See San Francisco Arts \& Athletics, Inc. v. U.S. Olympic Comm., 483 U.S. 522 (1987).

117. James Boyle, Shamans, Software, and SPLEens: LAW AND THE CONSTRUCTION OF THE INFORMATION SOCIETY 145-48 (1996).

118. I am not actually trying to engage the question of whether homosexuality is chosen or genetically endowed. I only suggest that whether one lives a life that is sexually fulfilling, given either a genetic or environmental context, is a matter of central importance about which an individual should be autonomous, and that autonomous choice is dependent on adequate access to information both about the availability of various ways of living a sexually meaningful life, and about their relative worth given one's endowment and context. 
engines. ${ }^{119}$ Playboy claimed that since her site was not authorized by the company, Welles could not use the alphanumeric string to identify her site as relevant to those interested in finding documents relevant to the term "playboy." 120 In the other case, Playboy challenged the practice of a search engine, Excite, of treating the term "playboy" as a general request for soft porn. ${ }^{121}$ Excite returned to users who searched for the term-in addition to sites authorized by the plaintiff-results that were not related to Playboy Enterprises, including advertisements by competitors together with the search results. ${ }^{122}$ But it is important to understand that what was at stake in these cases was whether a trademark right will give its owner the exclusive right to determine the range of options open to users who rely on its mark to search for sexual materials. Most importantly, they involve the question of whether the initial role played by the mark in signifying interest in sex permits the organization, Playboy Enterprises, to define for those who seek sexual materials what counts as "sex" or "sexually gratifying expressions."

As information about the world around us becomes increasingly diverse and dispersed, the right to control search engines, filters, and the very definition of relevance becomes the right to control the perceptions of individuals about what options are open to them. The right asserted by Playboy in these cases was a right to determine the range of options presented to users who initially expressed their interests using the term "playboy." And control over the range of options open to individuals is control over their choice. At stake in the Welles case was the question of how individuals can rely on their own understanding of the cultural signification of "owned" words to present themselves as relevant to others. At stake in Excite was to what extent trademark owners would be able to control the definition of cultural and social signification and whether they would receive an exclusive right to dictate the options presented to those who use their "owned" signifier to represent a choice or "search." In both cases, the result would be a more or less concentrated structure for the determination of relevant options open to one who uses a given signifier to define the choice one views oneself as making. The more centralized the structure, the more individuals seeing the world through the controlled lens come to

119. Metatags are descriptors inserted in a web page, but not viewable to human eyes, that are used to describe the content of the page to search engines. See Meta, 〈http://www.whatis.com/metatag.htm〉 (visited Apr. 13, 2000).

120. See Playboy Enters., Inc. v. Welles, 7 F. Supp. 2d 1098, 1101 (S.D. Cal. 1998).

121. See Playboy Enters., Inc. v. Excite, Inc., 55 F. Supp. 2d 1070 (C.D. Cal. 1999).

122. See id. at 1072. 
be controlled by owners of the rights to define signification and relevance, and the less autonomous these users become.

Information, then, is central both to democratic self-governance and to personal autonomy. Laws regulating control over information flows must therefore be subject to special care in our democracy, a care we have come to institutionalize in judicial review. In the case of exclusive rights to control the use of information, Part II suggested that judicial review should be applied using two vehicles-the threshold constraints imposed by the Intellectual Property Clause and the more context-sensitive constraints imposed by the First Amendment.

\section{B. "Progress" and the Political Economy of Enclosure}

In addition to the normative concerns surrounding enclosure of information, enclosure raises immensely important general welfare concerns that are systematically ill-represented in political processes. I will treat these problems using the admittedly quaint heuristic of "Progress," 123 the value to whose service the Intellectual Property Clause is dedicated. ${ }^{124}$

The structure of the modern idea of Progress from the mid-eighteenth century until quite late in the twentieth century provides a useful guide to

123. Basing any policy conversation on a notion of "Progress" at the beginning of a new millennium will probably strike many as quaint, ignorant, or irrelevant, and possibly all three. It might strike one as quaint or ignorant, because this concept, so central to European-North American political, economic, and social culture from the mideighteenth to the mid-twentieth century has been subject to extensive and sustained critique at least since the two world wars shattered the naive confidence in its beneficence. See, e.g., PROGRESS AND ITS DisCONTENTS (Gabriel A. Almond et al. eds., 1982); JAMES NISBET, HISTORY OF THE IDEA OF PROGRESS (1980). It might strike one as irrelevant because Progress is such a world-historical, communal concept, one that has to do with the condition of "civilization," or "humankind." These universalizing corporatist concepts seem increasingly irrelevant to our individual-centered conception of society, which is tempered mostly by recognition of subcultures and small-scale communities defined more often than not in opposition to the more universalizing corporatist concepts usually implied by Progress. Despite this oddity, I will nonetheless venture to think through the general welfare side of the question of the propriety of close judicial review of exclusive rights in information through the heuristic of "Progress." If you will, this is a standard exercise in constitutional interpretation rooted in text and the history of the value it embeds. Perhaps it is a new-found optimism of one living not only more than fifty years after Hiroshima, but also in a decade where instant satellite-borne news has pushed the international community to humanitarian action in Bosnia, Kosovo, and East Timor, where radio $\mathrm{B} 92$ could resist closing in Belgrade by moving to webcasting, on a medium invented only four or five years earlier-the Web. See Matt Richtel, Banned Belgrade Station Turns to the Internet, N.Y. TIMES, Apr. 1, 1999, at G3.

124. "To promote the Progress of Science and the useful Arts. ." U.S. CONST. art I, $\S 8, \mathrm{cl} .8$. 
understanding the stakes of exclusive rights in information or knowledge. ${ }^{125}$ In this quintessentially modern of ideas, Progress is the product of human agency, not the Divine. It is a forward movement whereby one generation builds on the attainments of its preceding generation, and in turn becomes the stepping stone of the next generation's improvements. The engine of Progress is the progress of knowledge. Knowledge itself, like Progress, advances through human agency and improves from one generation to the next in a process of accretion. It feeds technological innovation, which increases the spread of material welfare and the development of better organizational and institutional arrangements, all of which feed back on each other. Over time, these together lead to the intellectual, moral, and aesthetic improvement of the human condition. ${ }^{126}$ This too was the basic structure of the idea that animated the passage of the Intellectual Property Clause. $^{127}$

Understanding this structure of the idea of Progress is central to understanding why private rights in information and knowledge were understood by the drafters of the Constitution as "monopolies" to be carefully circumscribed, rather than as property rights to be cherished and protected. ${ }^{128}$ The object of property is Nature, given to industrious Man to make fruitful and thereby make his own. The object of exclusive rights in

125. See PROGRESS AND ITS DiSCONTENTS, supra note 123, at 5; NISBET, supra note 123, passim.

126. For a particularly succinct presentation of this structure of the idea, see PROGRESS AND ITS DISCONTENTS, supra note 123, at 5.

127. See NISBET, supra note 123 , at $198-200$. Nisbet quotes a particularly clear reiteration of this intellectual structure from one who is not normally mentioned in the debates over copyright or patent, as an example of the pervasiveness of this intellectual structure at the time; Adams opens his preface to Defense of the Constitutions of Government of the United States with the following statement:

The arts and sciences, in general, during the three or four last centuries, have had a regular course of progressive improvement. The inventions in mechanic arts, the discoveries in natural philosophy, navigation, and commerce, and the advancement of civilization and humanity, have occasioned changes in the condition of the world, and the human character, which would have astonished the most refined nations of antiquity. A continuation of similar exertions is everyday rendering Europe more and more like one community, or single family. Even in the theory and practice of government, in all the simple monarchies, considerable improvements have been made.

Id. at 199.

The structure of the idea of progress-the move from advances in knowledge to technology, to welfare, to organizational and institutional improvement (culminating in the American system, the best to that date)-is plainly visible in this paragraph.

128. See generally sources cited supra note 18. 
one's contributions to the Progress of knowledge is knowledge itselfKnowledge, not given in some Promethean transfer, but developed progressively over time, as one intellectual laborer adds to the common project, to be followed by others like him. More like Commerce ${ }^{129}$ than like Nature, Progress is a common enterprise, carried on by all, for the benefit of all. And like exclusive rights to Commerce-monopolies-exclusive rights to segments of the great process of Progress are to be feared and curtailed. Like a monopoly on tea, or a monopoly on printing, they are feared to be the product of faction preference, of a deal between the governor and some of the governed at the expense of the common good.

What is important to understand for contemporary purposes of institutional design is that insofar as the progress of knowledge is concerned, the basic assumption is that the politics of faction will lead to too much recognition of exclusive rights at the expense of the common good, whereas the major concern about the politics of faction with respect to traditional property was that it would lead to too little respect for property, by supporting redistribution at the expense of the common good. ${ }^{130}$

So, if we try to break down the core components of the concept of "Progress" into contemporary terms, we arrive at the following uncontroversial list. First, both theoretical learning and practical innovation are central to material well-being. ${ }^{131}$ Second, these advances are by nature incremental, with each new participant and each new generation building on the achievements of its predecessors, and building a platform upon which future participants in this process will themselves build. ${ }^{132}$ Third, the

129. On the idea of Commerce, see Carol Rose, The Comedy of the Commons: Custom, Commerce, and Inherently Public Property, 53 U. CHI. L. REV. 711 (1986).

130. See JENNIFER NEDELSKY, PRIVATE PROPERTY AND THE LIMITS OF AMERICAN CONSTITUTIONALISM: THE MADISONIAN FRAMEWORK AND ITS LEGACY (1990); Jennifer Nedelsky, Roads Not Taken: Undercurrents of Republican Thinking in Modern Constitutional Theory: Democracy, Justice, and the Multiplicity of Voices: Alternatives to the Federalist Vision, 85 Nw. U. L. REV. 232, 232-38 (1990) (discussing the centrality of the concern about property in the concept of the politics of faction).

131. See Joseph A. SCHUMPETER, CAPITALISM, Socialism, AND DEMOCRACY (1942). The central role of technology as the engine of growth, more than growth in capital or labor inputs, or in static allocational efficiencies, was given its most prominent imprimatur of empirical verification in Robert M. Solow, Technical Change and the Aggregate Production Function, 39 REVIEW OF ECONOMICS AND STATISTICS 312 (1957) (showing that of a doubling of productivity between $1909-49,87.5 \%$ of the growth was attributable to technological development, and $12.5 \%$ to increased use of capital).

132. See Suzanne Scotchmer, Standing on the Shoulders of Giants: Cumulative Research and the Patent Law, 5 J. ECON. PERSP. 29 (1991). This realization was introduced into what became the standard welfare economics model of intellectual property in Kenneth J. Arrow, Economic Welfare and the Allocation of Resources for Invention, in THE 
product of all the individual efforts making up the progress of knowledge leads to large scale, society-wide benefits at the material, organizational, institutional, and cultural levels. Knowledge production is, in other words, a high positive externality activity, whose external benefits accrue to diffuse beneficiaries in diverse ways. ${ }^{133}$

The first component of the list, the importance of innovation and the progress of knowledge to aggregate welfare, would not, by itself, counsel close judicial review. We do not, after all, think that courts are systematically better than legislatures at determining good policy. But the second and third elements of what might make for a contemporary, non-naïve understanding of "Progress," do suggest systematic weaknesses in the legislative process, weaknesses that judicial review could remedy.

The second element goes to the systematic intergenerational bias of legislators. If Progress is a joint enterprise of present and future generations, then an optimal policy in the pursuit of Progress must take into consideration the costs and benefits of any exclusive right in information to both present and future generations. But future information producers and future constituencies that benefit from their innovation do not vote for, or contribute to, present legislators. Only present participants do. What we are therefore likely to see is a systematic bias of legislators to provide exclusive rights-which favor present participants over future participants. Courts, not similarly beholden to present participants, are in a better position to take stock of the overall effects of a proposed law on the intergenerational enterprise called Progress. As among potential institutional decision-makers, they are the best residual bearer of the decision-making power, because they are the most insulated from the pressures of today's participants.

The third element - the recognition of the high positive externalities involved in information production-suggests that laws designed to respond to the interests of present producers by maximizing their private benefits will not systematically coincide with laws best tailored to optimize knowledge production. Say that a new law, for example copyright term extension, slightly increases the ability of producers to appropriate the benefits of their work but significantly limits the ability of society at large to capture the externalities created by a copyrighted work. It will rarely be the case that any individual in society bears the full public cost of these lost positive utilities as private costs. And, whenever no individual

RATE AND DiRECTION OF INVENTIVE ACTIVITY: ECONOMIC AND SOCIAL FACTORS 609, 616-17 (National Bureau of Economic Research ed., 1962).

133. See sources cited in Benkler, supra note 2, at 435 n.304. 
or organization sees the full public costs as private costs, the social costs of an increase in property rights will be underrepresented. Moreover, unless there happens to be an individual or organization who sees private costs that are on par with the benefits that the vendors see as private gains from the change in law, the benefits of the legislation will always be presented to legislatures as outweighing the costs. This leads to a systematic information imbalance whenever a legislature considers a measure to increase the scope of intellectual property rights. The public benefits of the measure are more completely reflected as private benefits for participants in the political conversation - the owners of the new rights-while the public costs are usually reflected as much lower private costs, for a much more widely dispersed constituency. Occasionally a set of costs may be reflected as private costs for a given constituency, and in those instances we would tend to see Congress addressing the costs presented to it by that constituency.

What we would expect to see from such a structure of the information flow into a legislative process is an expansion of rights over time, tempered by specific exemptions for those constituencies who happen to experience a particular set of public costs as private. And this is in fact what we see in the area of intellectual property law-systematic expansion of property rights tempered by exceptions and exemptions for groups who presented to Congress their own subset of the total social cost of the new rights. This structure dates back to Noah Webster's involvement in the passage of copyright acts in the states to protect his dictionary, ${ }^{134}$ and was nowhere more evident than in the drafting of the Copyright Act of 1976, so comprehensively described by Jessica Litman. ${ }^{135}$ More recently we saw it in the Digital Millennium Copyright Act, ${ }^{136}$ which vastly expanded the ability of providers of information in digital media to exclude non-paying users from their products, tempering this expansion with a long list of exemptions for specific constituencies. ${ }^{137}$ In the database bills considered in

134. See Walterscheid, supra note 18 , at $40-41$ (noting Webster's vigorous support for strong copyright protection, but casting doubt upon Webster's alleged influence on the drafting of the Intellectual Property Clause).

135. See Jessica Litman, Copyright, Compromise, and Legislative History, 72 CoRNELL L. REV. 857, 869-79 (1987) (describing the nature of that Act's provision as a negotiated settlement among specific stakeholders); see also Robert C. Denicola, Freedom to Copy, 108 YALE L.J. 1661, 1684-86 (1999).

136. Pub. L. No. 105-304, 112 Stat. 2860 (1998).

137. These include those engaged in law enforcement, intelligence, and other government activities intended to assure computer security; software manufacturers who reverse engineer a competitor's software, to the extent necessary to make the manufacturer's product compatible with that of the competitor; those engaged in encryption re- 
Parts IV and V below, there is no clearer example of this than the absolute exemption given in the broader of the two bills to religious use of genealogical information, apparently central to the practices of the Church of Jesus Christ of the Latter-Day Saints. ${ }^{138}$

Unlike legislatures, which can respond to no wider a range of social benefits and costs than those internalized at the time it is passed, judges encounter the legislation over time, as its social costs come to be borne as private costs by individual parties to the litigation before them. While courts cannot completely compensate for the informational imbalance regarding legislation that encloses information, over time they nonetheless have a potentially more comprehensive view of the social costs of the exclusive rights created by the legislature. Faced with the systematic informational bias in the legislative process, courts should recognize their relative advantage in observing the social costs of these laws and adopt the role of counterweight to balance the bias's effects.

\section{Conclusion}

This section suggested why we might want a robust system of judicial review for what might, at first glance, look like a normal governmental regulatory function. I proposed two answers. First, the way information flows in society, and decisions about who controls information flows under what circumstances, play a central role in defining our democracy, and in defining to what extent, and under what constraints, each of us can be an autonomous human being. Second, the political economy of regulating information flow is subject to systematic imbalance in the representation of present stakeholders relative to future generations, and in the representation of its private benefits relative to its social costs.

Judicial review is an appropriate institutional mechanism to recalibrate the process by which our society creates exclusive rights to control information flows in our information environment. Courts have traditionally played an important role in assuring the conditions of a well-functioning democracy and in protecting the value of personal autonomy against measures intended-at least purportedly-to advance the public good. Courts are also a good backstop against systematically unbalanced legislative and regulatory processes because they march to the beat of a different

search; those engaged in excluding minors from Internet materials; users, to avoid revealing personally identifiable information about the user to the owner of the protected materials; and those engaged in bona fide security testing of computer systems. See id. $\S$ 1201 (e)-(i).

138. See H.R. 354, 106th Cong. § 1403(h) (1999); see also infra note 166. 
drum, can take a longer view of the effects of laws, and are presented with arguments from equally engaged parties.

\section{CONSTITUTIONALITY OF THE DATABASE PROTECTION BILLS UNDER THE INTELLECTUAL PROPERTY CLAUSE}

If the House of Representatives had purposefully tried to create a test case of the constitutional bounds imposed on it by the Intellectual Property Clause, its members could not have done better than to propose the two main opposing database protection bills reported to the House on September 30, 1999. House Bill 354, reported from the Committee on the Judiciary by Representative Coble, creates a property right in raw information in all but name. As reported, House Bill 354 prohibits extraction of information from a database, both for reuse and dissemination and simply for use, and gives database owners the right to track and prevent uses of information extracted from their database into downstream products-whether or not they compete with the database. The report suggests that the law is intended to secure incentives for investment in databases and to prohibit most valuable uses of information obtained from the database without the owner's permission. House Bill 1858, reported from the Committee on Commerce by Representative Bliley, on the other hand, assiduously shies away from property, and attempts to remain within the confines of unfair competition. It addresses competitors only, not users-either consumers or downstream creative users. It prohibits duplication, defined narrowly as slavish copying of the contents of the database without adding value, for sale of this data in competition with the source database. And it vests enforcement in the Federal Trade Commission. As one reviews the background and components of each proposed law, it becomes clear how House Bill 354 fails both the threshold test imposed by the Intellectual Property Clause and the backstop constraint imposed by the First Amendment, while House Bill 1858 survives at least the former, and probably the latter. This part reviews the constitutionality of the two bills under the Intellectual Property Clause, while Part V reviews constitutionality under the First Amendment.

\section{A. Background}

In 1991, in Feist Publications, Inc. v. Rural Telephone Services Co. ${ }^{139}$ the Supreme Court held that raw facts in a compilation, or database, were not covered by the Copyright Act, and could not be so protected consistent

139. See discussion supra text accompanying notes 27-38. 
with the constraints imposed by the Intellectual Property Clause. ${ }^{140}$ The Court held that the copyright law could protect the creative element of the compilation, its organization or selectivity, for example, ${ }^{141}$ but could not protect the facts compiled. There are conflicting accounts of whether Feist thereby broke with a widespread practice of protecting "sweat of the brow" works - works created by investment of money and labor, but lacking creativity-or whether the Court merely acknowledged, adopted, and embedded at the constitutional level the general trend among the lower federal courts. ${ }^{142}$ What is not debated is that the past few years have seen repeated efforts to pass legislation that would remedy the perceived deficiency that the Court's holding in Feist created-namely, that producers of investment-intensive, uncreative collections of information did not have a property right in data they collected.

That the Court rooted its Feist decision in a robust interpretation of the Intellectual Property Clause created something of a difficulty for those seeking that holding's legislative nullification-namely, it did not seem possible for them to do so without running afoul of the Intellectual Property Clause. ${ }^{143}$ Efforts to protect database providers therefore eventually settled not on a sui generis quasi-property right, as that recognized in the European Database Directive, ${ }^{144}$ but rather on an unfair competition law, which could be based in the Commerce Clause, free and clear of the inconvenient weight of Feist.

This background has created a rather unique natural experiment for testing the bounds imposed by the Intellectual Property Clause on Congress. We know from our general constitutional analysis that intellectual property rights must be passed, if at all, within the confines of the Intellectual Property Clause. Only protections that are different in kind can be passed under the more general commerce power. ${ }^{145} \mathrm{We}$ also know, from Feist, that intellectual property rights cannot, consistent with the requirements of the Intellectual Property Clause, be recognized in the factual contents of a database, but only in its creative elements. What we now face is

140. See Feist Publications, Inc. v. Rural Tel. Servs. Co., 499 U.S. 340, 349-50 (1991).

141. See id. at 348-50.

142. See Collections of Information Antipiracy Act: Hearings on H.R. 2652 Before the Subcomm. on Courts and Intellectual Property of the House Comm. on the Judiciary, 105th Cong. (1999) [hereinafter CIAA Hearings].

143. See Pollack, supra note 1 , at $54 \mathrm{n} .44$ (citing contributions to the debate of just how fully Feist bound Congress not to pass such legislation).

144. See Council Directive 96/9/EC of 11 March 1996 on the Legal Protection of Databases, 1996 O.J. (L 77) 20.

145. See supra text accompanying notes 67-69. 
the task of examining competing efforts in Congress to protect database providers, to see whether they in fact provide a different kind of protection, or whether they are, functionally, an attempt to legislate a quasiproperty right.

\section{B. The Method of Comparison}

The Intellectual Property Clause captures not only legislative efforts that are formally aimed at creating intellectual property rights, but also those that create exclusive rights that are functionally equivalent to intellectual property rights. ${ }^{146}$ I therefore suggest here that the relevant comparison between the database protection bills and intellectual property is one of function, and here I will focus on economic function. The economic function of intellectual property rights is to provide the legal entitlement that makes information goods partly excludable. ${ }^{147}$ The technological and legal characteristics of every good locate it somewhere along a range from fully a public good to fully a private or economic good, as defined by the degrees to which the good is rival and to which it is excludable. ${ }^{148}$ Whether a good is rival or nonrival is solely a function of the state of technology. It either can, as a practical matter, be used by many people simultaneously without anyone's use rivaling that of another, or it cannot. Whether a good is excludable-whether its producer can as a practical matter prevent some or many people from using the good unless they promise to pay-is both a question of technology and of law. Land is excludable partly because fences can be built and partly because trespass is prohibited, so that jumping the fence will trigger a visit from the sheriff. Property rights in any given good define the parameters of its excludability in conjunction with nature.

Intellectual property rights define the excludability of information products. In order to provide producers of information goods with an incentive to produce, intellectual property rights give their owner a degree of exclusivity in controlling the use of "their" information product. They do so by stating an entitlement, and coupling it with a promise by the state to prevent users who seek to make use of the information in ways covered by the law from doing so. Since those uses are valuable to some users of the information, the owners sell permission to use to those users, and thereby appropriate the benefit that their productive enterprise has created for the users.

146. See id.

147. On the meaning of excludability and its relation to information, see supra note 23.

148. See id. 
Intellectual property rights are in this sense market-creating-they are constitutive of the properties of the goods sold in the market. Functionally, this distinguishes them from laws that are market-regulating, or that constrain behavior in a market for goods whose excludability is already defined by other rules-namely, property rights. Now, it should be clear that these definitions are provisional working definitions, and their borders are permeable. But they capture rather well, for example, the distinction between fair use, a limitation on all information product owners' ability to exclude users from their products, and misuse of copyright, a limitation on some owners' ability, under certain circumstances, to do things with their products that they are generally entitled to do. Even though it is formally a defense to a copyright claim, the former is a part of the definition of property in information and not part of the definition of the owner's exclusive rights. The latter, misuse, is a regulation of using already-defined property rights in certain market situations.

In interrogating the two database protection bills, we should seek to identify whether what each one does is market-creating or marketregulating in the sense just described. One inquiry would require us to identify the relationship addressed by the law: is it a relationship between sellers and buyers, producers and consumers, defining what is up for grabs between them, or is it some other relationship in the market, in particular, the relationship among competitors. Another inquiry concerns what actions are made possible or impossible by the law. In particular, we would be interested in whether the actions prohibited include the uses intended by the owner to be the source of the information's value to users. By prohibiting such actions, the law defines the "goods" that form the basis of a business in selling the information-or, more accurately, permission to make valuable use of the information. In the alternative, we might see that the prohibited actions are not those that make the information valuable to users, but rather those that permit competitors of the producer to provide the same value to users as the owner plans to sell.

\section{A Functional Comparison of House Bill 354 and House Bill 1858}

\section{Whom Does the Law Address?}

House Bill 354 is addressed to anyone who distributes information extracted from a database, ${ }^{149}$ and to anyone who uses information in a data-

149. See H.R. 354, 106th Cong. § 1402(a) (1999) ("Any person who makes available to others, or extracts to make available to others."). 
base. ${ }^{150}$ House Bill 1858 has two parts, the first plainly addressed to competitors, ${ }^{151}$ the second to anyone who distributes real-time market information. ${ }^{152}$ As an initial matter, then, House Bill 1858 does not speak to anyone who uses information (including real-time market information) for its value as information, as opposed to its value as goods in trade. House Bill 354 , on the other hand, does address anyone who uses the information in its marketable use, and could therefore, at least in principle, speak to a user for whom the value of use is precisely its value as data, not as goods in trade. It speaks to consumers of data, as well as to competitors in the market for serving consumers in data.

To illustrate the difference between the two, let us look at a simple example. Imagine that John purchases a CD-ROM with a list of daily temperatures, barometric pressure, and other such data, in 200 cities and towns throughout the United States between 1900 and 1999. He lends it to Jane. Jane copies the entire factual contents-but not the organization-of the CD-ROM onto her hard drive, where she now accesses the raw information using her own access software, having returned the CD-ROM to John. Clearly what Jane did would violate copyright, if the contents of the CD-ROM had been copyrightable, and no other factors were present. Equally clear, her actions are privileged from copyright law under Feist, because that decision was not based on a notion of fair use or de minimis use, but on the uncopyrightability of facts, which are in the public domain, free for the taking.

House Bill 1858 does not speak to Jane. She is not disseminating the information in commerce. House Bill 354 does speak to her. She has extracted the entire collection of information. Now we must determine whether her extraction harms the producer's primary market, and if so, whether or not she is privileged under one of the exceptions included in the Act. But we do not need to make that assessment to complete identifying the first central difference between the two bills. House Bill 354 is addressed to users of the information who use it for its value to them as information, as well as to competitors and others who distribute the information extracted from protected databases. House Bill 1858 is addressed only to competitors of the information provider, or with respect to real-time

150. See id. § 1402(b) ("Any person who extracts all or a substantial part of a collection of information.").

151. The Bill establishes that is unlawful to sell or distribute in interstate commerce a duplicate of a database that "is sold or distributed in commerce in competition with that other database." H.R. 1858, 106th Cong. § 102 (1999).

152. See id. $\S 201$ (addressing anyone who obtains real-time market information and directly or indirectly disseminates it without authorization). 
market information, to those who redistribute that information on a realtime basis.

\section{What is Prohibited to the Law's Addressees?}

House Bill 1858 prohibits distribution or sale of a duplicate of a database. ${ }^{153}$ A duplicate must be both "substantially the same" as the original, and must have been created by extraction of the information from the original. $^{154}$ The Committee Report explaining the definition of duplicate suggests that a database is not "substantially the same" unless the nonidentical portion of the duplicate is immaterial to the overall value of the database. ${ }^{55}$

House Bill 354 prohibits both extracting to make available and making available information from a database in a manner that causes material harm to the primary or a related market of the producer of the source database, ${ }^{156}$ and prohibits extracting information in a manner that causes harm to the producer's primary market. ${ }^{157}$ The Committee Report on Section 1402 suggests that "material harm" is intended to exclude de minimis uses, but not to introduce a more robust limitation, ${ }^{158}$ expressly rejecting the requirement imposed in National Basketball Ass'n v. Motorola, Inc. that the plaintiff must show that use of the facts in the manner the defendant uses it would threaten its existence. ${ }^{159}$

One implication of this difference reinforces the point made in the preceding section. The Committee Report on House Bill 354, in explaining the meaning of "material harm," includes the following statement: "[I]f a person extracts so much of an online database that the person would, in the future, be able to avoid paying a subscription fee for access to the data it contains, that person has harmed the market for the database." 160 Again, House Bill 1858 would not speak to such a person, whose extraction is for personal use and not for competition.

Moreover, this paragraph in the report illustrates that part of the function of House Bill 354 is to create the legal basis upon which the provider

153. See id. $\S 102$.

154. Id. $\S 101(2)$.

155. H.R. REP. No. 106-350, pt. 1, at 16-17 (1999).

156. See H.R. $354 \S 1402$ (a).

157. See id. $\S 1402$ (b).

158. See H.R. REP. NO. 106-349, pt. 1, at 18 (1999).

159. See National Basketball Ass'n v. Motorola, Inc., 105 F.3d 841, 845 (2nd Cir. 1997) (limiting hot-news claims to cases where, inter alia, "the ability of other parties to free-ride on the efforts of the plaintiff or others would so reduce the incentive to produce the product or service that its existence or quality would be substantially threatened").

160. H.R. REP. NO. 106-349, pt. 1, at 18 (1999). 
of a database can claim an entitlement to payment. In the absence of House Bill 354 the producer can physically block access to the information, and charge for access as a contractual matter. But the producer has no legal right to use the machinery of the state to prevent a user who has gained access to the information from using it, and hence has no legal claim to payment in the absence of a contract. As the quote from the Committee Report in the preceding paragraph makes clear, House Bill 354 creates this right, which is the essence of a property right - the right to exclude another from using one's property, irrespective of whether one has, or has not, maintained physical control to implement that exclusion.

Another conceptual difference between the two bills, that goes to the "propertyness" of House Bill 354, is how differently they "track" the rights of a producer in something like the "res" of the collection. Imagine that Jane, in our example above, uses the information about the weather in 200 U.S. cities as part of a compilation of similar data for 5000 cities around the world that she is producing. Under House Bill 1858, the value of the 4800 cities that she added in her database (perhaps by similar extraction from other small databases) would not be "immaterial to the overall value" of her database. Accepting the interpretation that the committee placed on what makes one database "substantially the same" as the original of which it is purported to be a duplicate, her new database would not be "a duplicate," and would therefore not violate the prohibition imposed by House Bill 1858. The report on House Bill 354, on the other hand, expressly contemplates such use of the entire contents of a database, and explicitly treats it as a prohibited act. The example used in the report is of a person who compiles a collection of public domain photographs of famous people around the United States by including, among other things, a collection of public domain photographs of such people from Massachusetts. ${ }^{161}$ As the Committee Report puts it, "[t]he Act seeks to prevent market harm to the investment in collections of information, and defendants should not be able to escape liability through activity analogous to the use of a stapler."162 Once the investment in collecting is made, its value to others, including others who use it as input into their own value-added production, is captured by the law for the benefit of the collector. The collection ceases to be a set of facts, and becomes a res that can be tracked back to its original owner through successive compilations. Again, what we see is that the collection of facts becomes an excludable good because

161. See id. at 17-18.

162. Id. at 18 . 
of this proposed law, one that can be sold-or not-to future producers who value it, whether or not they compete with the original collector.

Beyond this conceptual level, it is important to understand that House Bill 1858 and House Bill 354 regulate two different kinds of competitive harm-one that has traditionally been the subject of unfair competition, the other of intellectual property. Take the example given in the Report on House Bill 1858. ${ }^{163}$ One database producer ("A") collects information about bank loans from in-state individual bank databases, and creates a statewide database more efficient than those each bank produces. A second database producer ("B") takes A's collection, combines it with out-ofstate individual bank information, and provides a more comprehensive database still. According to the Committee Report on House Bill 1858, the bill privileges the use that $A$ made of the individual bank databases, and that B made of A's database. In each case, the second database producer in each pair (bank, A), (A, B) added significant information value to the information copied from the first database in each pair. This additional information is material to the value of the second database in each case, the second database is therefore not a "duplicate," and the use of the existing information collection is privileged. Under House Bill 354 both A's and B's actions would be prohibited. House Bill 1858 would, however, cover the behavior of each of A-vis-à-vis the banks-or B-vis-à-vis A, if the second database in each case had done nothing more than copied all of the prior database, and then sold that duplicate without adding much of value.

House Bill 1858 thus provides protection against a competitor who competes by offering the same product, and who can sustain a lower price for that product solely by relying on its competitor's investments in collecting the information. House Bill 354 protects against this competitor, but in addition protects against a competitor who competes by offering a better and more comprehensive product that is fully or partially substitutable with the original product, which does not even necessarily undercut the original database producer in price, but is cheaper than it would have been had the competitor been prohibited from using existing information collections as raw materials for its better product. Such protection encumbers the subsequent producer with a production price that is higher than the social cost of its production at the time it is undertaken, and hence diminishes the production of these later, better products, to below their socially optimal level at that later time. This intergenerational tradeoff is the standard effect of intellectual property rules, but not of unfair competition law.

163. See H.R. REP. No. 106-350, pt. 1, at 8 (1999). 
In effect, House Bill 354 functions economically like an intellectual property rule. If it is truly about unfair competition through price undercutting made possible by free-riding on the investment of another, it need not cover as many uses of information contained in databases as it does. Protection of the type provided in House Bill 1858 does that job. If it is about requiring the makers of advanced products to pay a fee to the makers of precursors and of information inputs they use in their products, then it is not about unfair competition-it is about dividing the welfare produced by investment in the collection, organization, and dissemination of information, such that subsequent producers pay predecessors who made their new production possible. It is about trading static efficiency of information production for dynamic efficiency. It is about intellectual property.

\section{Exceptions, Limitations, and Enforcement}

House Bill 1858 has fewer exemptions and limitations, because the scope of its initial reach is much narrower. House Bill 354 has many more limitations and exceptions. The most important for our purposes is the list of permitted acts under Section 1403-some of which create contextspecific exceptions to liability, and others of which in fact limit the extent of the property right created by the bill. The most important limitations on property in facts are that extraction or dissemination of an individual fact contained in a database is permitted, and that collected facts remain in the public domain in the sense that competitors are free to collect them independently. The property right created in the investment in compilation, however, is maintained by prohibiting repeated extraction of individual facts - thus limiting this exemption, as with the definition of "primary market," to de minimis instances of extraction-and by prohibiting collection of the facts by accessing the collection.

The remaining permitted uses provide exceptions for certain specified uses. These, however, do not change the nature of the right created, but only define its contours. There is a general reasonable use exemption, which requires context-specific weighing of factors, somewhat like the fair use defense in copyright. What is important to note about this exemption is that it does not affect its nature as a property-like right. Just as the scope of "fair use" defines the scope of the copyrights authors have in their writings, but does not change the nature of copyright from an intellectual property right into an unfair competition rule, so too the availability of a reasonable use exemption does not change the nature of the database protection right created in House Bill 354 from an intellectual property-like 
right into an unfair competition law, but merely defines the scope of the property right.

It is not that a list of permitted uses could not, as a conceptual matter, have, if Congress so chose, fundamentally altered the nature of the right. If the permitted acts had in fact negated the basic reach and effect of the prohibitions stated in Section 1402, they would have, effectively, negated our initial conclusion that House Bill 354 creates a property right. But that is not what they do. A comparison between the exemption for nonprofit educational and research uses and the exemption for genealogical information collected or used for religious purposes is instructive.

Section 1403(c) exempts nonprofit educational and research uses that do not harm the primary market of the information provider. This is an exemption intended to permit education and research uses of investments made in collecting information for various other markets without payment, and is a real limitation on a general property right. Nonetheless, it retains the structure of a property right in the information collected to form the basis for a provider that treats nonprofit educational and research users. as a primary market. "Primary market" is defined in the bill to include any market in which the provider offers a service or product incorporating the database, and from which the provider reasonably expects to receive revenue. ${ }^{164}$ If the collection of information is offered for sale to educators or researchers, even only as a sideline business, then the exemption does not apply, and the provider can charge for the use. The users have no exemption from the prohibition on using the information. This exemption retains, therefore, the market-creating role of House Bill 354, as to the market in information useful in education and research. For example, a company would be protected from this exemption if it invested in collecting information from public records about family histories and offered them in a CD-ROM for use in classrooms in the study of personal family history, or to researchers of migration patterns. The exemption would not apply even if the business rationale that justified the compiler's investment in compiling the data were based purely on the value of the compilation for family entertainment, so that the existence or non-existence of the nonprofit educational or research market were irrelevant to the investment decision.

The same company that collects family history information cannot, however, decide that there is a market for its efforts among members of

164. See H.R. 354, 106th Cong. § 1401(3) (1999). This definition of primary market is complemented by a "related market," in which the provider does not yet offer the data, but in which others who offer similar databases do sell, or which the provider demonstrably is preparing to enter. See id. $\S 1401(4)$. 
the Mormon Church, who might be willing to pay a good deal to find information about their families because this information would help them to perform church ordinances for their deceased ancestors. ${ }^{165}$ These religious users of genealogical information are entirely exempt from the Act's coverage, irrespective of the effect on the producer's intended primary market. ${ }^{166}$ This is a form of exemption that excludes a property right in certain kinds of information-genealogical information useful for religious observance. It makes religiously useful genealogical information nonexcludable, and hence not the object of market transactions. Were the "permitted acts" enumerated in section 1403 generally of this structure, the property right would, indeed, be negated in many cases.

Another important practical difference between House Bill 1858 and House Bill 354 is in the enforcement mechanism. The general prohibition on duplication in competition under House Bill 1858 is enforceable by the Federal Trade Commission ("FTC"). ${ }^{167}$ There is no private right of action (although there is such a right for the bill's second part, dealing with misappropriation of real-time market data). House Bill 354 does provide a private right of action. ${ }^{168}$ This practical difference is important as a prudential matter. On the one hand, this limitation might render the protection ineffective by subjecting enforcement to the budget and personnel constraints of the FTC. On the other hand, it provides an important backstop against overreaching assertions of rights, if that is what one is concerned with in the database context.

These practical effects may be important, but they do not affect the constitutionality of the database laws under the Intellectual Property Clause. That trademark rights can be asserted by private owners does not make them any more, or any less, distinct from intellectual property rights of the variety that must be passed, if at all, under the Intellectual Property Clause. Similarly, that the securities laws permit private rights of action to enforce their disclosure requirements does not convert the regulatory reporting requirements into property rights of shareholders. They remain nonwaivable background rules intended to assure the efficiency of the market, not rules that define the contours of securities as objects in trade. Nor do private rights of action under the antitrust laws make these laws

165. For a description of the role descendents have in performing ordinances for their ancestors who were not fortunate enough to hear the gospel themselves, see Gospel Principles, Temple Work and Family History 〈http://www.lds.org/library/gos_pri/U08_C40Temple_Work.html (visited April 26, 2000).

166. See H.R. $354 \S 1403(\mathrm{~h})$.

167. See H.R. 1858, 106th Cong. § 107 (1999).

168. See H.R. $354 \S 1406$. 
into property rights for consumers. That a database owner can trigger enforcement by bringing a private suit similarly should not be the touchstone of whether the right the database protection law provides is an exclusive right of the type that must be passed under the Intellectual Property Clause.

\section{Conclusion}

The thesis and function of House Bill 354 are identical to those of the Copyright Act or the Patent Act. The thesis of these intellectual property laws is that producers of valuable information goods require legal protection to enable them to appropriate the benefits of their productive investments. To give producers this incentive, users who find the information valuable are prohibited from making use of the information, and producers are given the power to remove that prohibition. The users, in turn, pay the producers for lifting the prohibition, thereby creating a market in the information products of the producers and creating the incentive for production.

House Bill 354 operates on exactly the same assumptions, progressing in exactly the same fashion to enact a market-creating property right in collections of information. Its prohibitions are intended to apply to all users, both consumers and producers-whether these producers compete with the owner or not-and they are intended to permit providers to charge for all but de minimis uses. Notwithstanding the claims in the Committee Report that the bill would enact a competition rule, comparison with House Bill 1858 suggests that this is not the case. House Bill 354 addresses users, as well as competitors. It prohibits simple use of the information for its core utility, in addition to competitive use of the information as goods in trade. It tracks the collection downstream, and attaches a right to the use of the information even where it is used transformatively, for the value its information contents provide in avoiding the cost of regathering the information. In this too it is like a property right, attaching to composite products that incorporate the thing in which the property right is àsserted.

House Bill 1858, on the other hand, addresses only competitors, not users. It prohibits only competition that free rides on the investment of a competitor to a degree that threatens the viability of the original database producer, but does not prohibit transformative use that builds on the investments of predecessors to make new information available to society. The bill is different from copyright or patent rights, and more similar to at least the confusion arm of trademark protection, which addresses competi- 
tors, not consumers, and prevents only competitors' actions that interject the competitor between the plaintiff and its intended customers.

As Part II explained, the Intellectual Property Clause requires that intellectual property-like rights in information be enacted, if at all, only within the confines of that clause. In Feist, the Supreme Court stated that that clause did not permit recognition of property rights in the information contents of a collection. In regulating information markets under the general commerce power, Congress may only enact regulations that are different in kind from intellectual property rights, like trademark protection. House Bill 354 is functionally an intellectual property right in the information contents of databases, cannot be passed under the Commerce Clause, and is unconstitutional under the Supreme Court's interpretation of the Intellectual Property Clause throughout this century, and more specifically in Feist. House Bill 1858, on the other hand, is a law that regulates one particularly ruinous form of competition, and can therefore properly be passed under the Commerce Clause.

\section{CONSTITUTIONALITY OF THE DATABASE PROTECTION BILLS UNDER THE FIRST AMENDMENT}

\section{A. Parameters of Analysis}

Recognizing exclusive private rights in valuable uses of information requires that government abridge the freedom of some people-putative users - to use information, at least sometimes. ${ }^{169}$ It is the prohibition on certain uses of information that forms the basis for the market in permissions to use the information. I have elsewhere explained in detail my view that laws creating private rights in information should always be subject to the same level of review as is structural media regulation. ${ }^{170}$ In order to implement structural media regulation-say, require cable operators to carry broadcast signals-government tells one person that it cannot (or must) communicate in ways that it does (or does not) wish to. Government has no suppressive purpose and may be seeking to improve the quality of communications in society. Nonetheless, the structure of the regulation is to force one person-the regulated party-not to communicate in a manner that that person could communicate, absent existence of the law. Similarly, intellectual property rules tell the user that he or she may not communicate in certain ways-read, copy and distribute - that that regulated person could have communicated but for the regulation. The government's

169. See Benkler, supra note 2 , at 390-94.

170. See id. at 364-86, 390-94, 408-12. 
intent is not to suppress speech, but rather to enhance information production. But the means it has chosen require it to prevent someone from speaking in a way that she wants to and can. This requires heightened scrutiny to see that the government is serving an important interest using means that are no more restrictive than necessary. ${ }^{171}$

Moreover, irrespective of how broadly one reads the Supreme Court's decision in Harper \& Row, it is clear that the Court treated the basic requirements that it elsewhere rooted in the Intellectual Property Clausenamely, originality, exclusion of facts from coverage, etc. ${ }^{172}$-as the reason that intellectual property rights dwell in peace with the First Amendment. This reliance suggests that courts should review with particular care legislation that creates exclusive rights in information without adhering to these principles, under a different congressional power that does not require such adherence.

Both database protection bills require certain people-competitors and users in the case of House Bill 354, and competitors and redistributors of real-time market information in the case of House Bill 1858-not to communicate certain information that they wish to and can communicate. The first part of House Bill 1858, and most of House Bill 354, is, like copyright, content-neutral, in that their purpose is detached from the content of the regulated communication. ${ }^{173}$ (The second part of House Bill $1858,{ }^{174}$ and at least the exception for genealogical information in House Bill 354, is content-based and must be subject to the strictest First Amendment scrutiny. ${ }^{175}$ )

In order to pass muster under the intermediate level of review, the government must establish that the challenged law "furthers an important or substantial governmental interest," that the interest "is unrelated to the suppression of free expression," and that "the incidental restriction on al-

171. See Turner Broad. Sys. Inc. v. FCC, 512 U.S. 622, 662 (1994).

172. See supra Part II.A.

173. See supra, note 85 (discussing content-neutral vs. content-based nature of these laws).

174. That part, section 201, applies to "real-time market information," which is clearly a content-based definition in that person A is entitled to communicate information in real-time about art exhibits, but not about stock prices, and the purpose of the prohibition is to protect this specific kind of information.

175. While the exception provides preferential treatment for, rather than burdens, religious use of genealogical information, one might easily imagine members of another religion that requires a different kind of information challenging the preference for genealogy, or a non-religious organization in need of access to different kinds of information challenging the content-based discrimination against their use of the information they needed. 
leged First Amendment freedoms is no greater than is essential to the furtherance of that interest." ${ }^{, 176}$ Stipulating that database protection law is not intended to suppress speech, this standard requires us to consider two questions: first, whether either or both bills further an important governmental interest, and second, if so, whether the manner in which they do so is significantly more speech-restrictive than necessary to serve the interest. The first part of the inquiry requires that we identify what the interest is, that we assess whether it is in fact "substantial," and that we evaluate whether the law furthers it. The latter part of the test suggests that we consider alternative avenues and their relative efficacy in attaining the goals identified in the first step, including in this case, comparing the two bills to each other in terms of relative efficacy and cost in free speech terms.

\section{B. Identifying and Evaluating the Goals of Database Protection}

Both Committee Reports include extensive statements of purpose, which of necessity must be our starting point in evaluating the government interest underlying Congress's action.

The House Bill 354 Report begins with the statement that the bill

responds to a need to supplement copyright law to prevent the wholesale copying of another's collection of information in a manner which [sic] harms the market for that collection. The bill ensures incentives for investment in the production and dissemination of collections of information, while maintaining continued access to information contained in such collections for public interest purposes such as education, science and research. ${ }^{177}$

The Report goes on to explain that electronic collections are "indispensable to the United States in the new information economy." 178 It states that "[d]eveloping, compiling, distributing, and maintaining commercially significant collections requires substantial investments of time, personnel, and effort and money."179

The Committee Report describes its understanding of the legal backdrop of collections of information. The description states as fact a quite controversial set of claims about the historical availability of protection for databases, ${ }^{180}$ whose upshot is that copyright law provides either no, or too

176. United States v. O'Brien, 391 U.S. 367,377 (1968).

177. H.R. REP. No. 106-349, pt. 1, at 9 (1999).

178. Id.

179. Id. at 10 .

180. The description even digresses to grammatical sleight of hand when, for example, it states that "[h]istorically, protection of collections of information has always been recognized as a branch of copyright law." This is a true statement that omits that, for 
thin a protection for database producers. This description outlines the gap that the Committee Report sees in the law. This gap, the object sought to be corrected by the bill, is the absence of protection-since Feist-against a competitor "lifting massive amounts of factual material from a copyrighted database to use as the basis for its own competing product." ${ }^{181}$ The committee then goes on to describe the passage in Europe of the European Directive on Legal Protection of Databases, ${ }^{182}$ and suggests that failure by the United States to pass commensurate protection "could place U.S. firms at an enormous competitive disadvantage throughout the entire European market." 183 It adds that there are debates in the World Intellectual Property Organization as to whether a sui generis property right in databases should be developed, and offers its solution as a competing, copyright-related alternative to such a property right. ${ }^{184}$

Finally, the committee describes digital technology as a potential threat to database producers' incentives, because it makes "[c] opying factual material from another's collection, and rearranging it to form a competing information product ... cheaper and easier than ever.... Furthermore, piracy and personal theft of collections developed through the resources of another is easy to achieve and will be rampant without proper protections for producers." ${ }^{, 185}$ Note that this is the first, and only, time in the report or the bill text that "personal theft" or personal use is mentioned

most of this period, in most courts, such protection was denied under the only law thought relevant; or, in order to describe the state of the law as one with which the present bill would be continuous, rather than the radical departure (whether justified or not) that it is, it claims that "[d]atabases or compilations have been protected by copyright in some form since 1790, when the first U.S. Copyright Act was amended" -also true, but only because of the "or," and because "compilations" means compilations of copyrightable works, as well as compilations of facts. See H.R. REP. No. 106-349, pt. 1, at 10 (1999). Similarly, in describing Feist, the report states that

the Supreme Court affirmed that originality and creativity in addition to investment and effort are required for protection under the Copyright Act, and that a related form of protection would have to be created in order to completely protect compilations or portions of compilations in which there is effort and investment but not a threshold level of originality or creativity.

Id. In fact, while Feist most certainly affirmed the necessity of creativity and originality, it did quite the opposite of "affirming" that a related form of protection would have to be used to protect unoriginal, noncreative facts. What the Court in Feist actually did was to state specifically that Congress lacked the power to enact such related protection.

181. H.R. REP. No. 106-349, pt. 1, at 10 (1999).

182. See Council Directive 96/9/EC, supra note 144.

183. H.R. REP. No. 106-349, pt. 1, at 11 (1999).

184. See id.

185. Id. (emphasis added). 
as a reason for the law. Needless to say, stating that a law is needed because "theft" will be rampant unless we pass the very law that converts what is now privileged use into "theft" is circular. Note further that this non sequitur is the only place where a need for a law that would exclude users, rather than competitors, from extracting information from databases, is mentioned or explained in the report or the bill.

In conclusion the report states that these factors necessitate passage of the bill

to protect developers against piracy and unfair competition, and thus encourage continued investment in the production and distribution of valuable commercial collections of information. Such legislation will improve the market climate for collections of information in the U.S.; ensure protection for U.S. collections abroad on an equitable basis; place the U.S. on the leading edge of an emerging international consensus; and provide a balanced and measured response to the new challenges of digital technology. ${ }^{186}$

In order to pass constitutional muster, a law must advance an important government purpose that addresses a "real harm" in a manner that will "alleviate it in a material way." 187 Conspicuously absent from the report is any evidence that there is any "real harm" to address-that the database industry needs any new protection, other than that which it can muster under copyright law, contract law, existing unfair competition law, and technological protection measures. ${ }^{188}$ The report says that digital technology changes conditions such that in the absence of a new law "piracy and personal theft ... will be rampant," but offers no evidence to support that in the more than decade-long experience of electronic databases the database industry has languished in the absence of protection. ${ }^{189}$ It says that failure to pass the law "could" place United States firms at a competitive disadvantage in Europe, but identifies no evidence that European competitors

186. Id.

187. Turner Broad. Sys., Inc. v. FCC, 520 U.S. 180, 195 (1997); Turner Broad. Sys., Inc. v. FCC, 512 U.S. 622, 663-64 (1994).

188. There is serious academic debate over whether these sources offer sufficient protection. See, e.g., J. H. Reichman \& Pamela Samuelson, Intellectual Property Rights in Data?, 50 Vand. L. Rev. 51, $55-57$ (1997); see also Jane C. Ginsburg, Copyright, Common Law, and Sui Generis Protection of Databases in the United States and Abroad, 66 U. CIN. L. REV. 151, 169 (1997).

189. See H.R. REP. No. 106-349, pt.'1, at 11 (1999). 
were pirating the contents of American databases. ${ }^{190}$ Indeed, the rallying cry "protect our database producers from the Europeans" rings hollow when testimony suggested that of the three major industry stakeholders only one, McGraw Hill, is an American company, while another, ReedElsevier, is a European company. ${ }^{191}$ (The third was Thompson, a Canadian company. ${ }^{192}$ )

Most importantly, there is no evidence cited or testimony to support the notion that Feist slowed down or in any way affected the database industry. Given the strong claim that Feist changed the legal background on which the database industry operated, ${ }^{193}$ it should have been relatively simple to conduct an empirical study to look at trends in the industry before and after Feist. One would expect such a study to show at least retardation in the rate of growth, if not a more pronounced negative effect on the commercial side of the database industry. Indeed, such a study was conducted, and introduced in Congress, as we shall see in looking at the Committee Report for House Bill 1858. ${ }^{194}$ It suggested that the commercial private database industry was alive, healthy, and unaffected by the absence of protection of the type introduced in House Bill 354, and rendered unconstitutional in Feist. ${ }^{195}$

The absence of evidence of a real problem is particularly troubling given the extensive criticisms of the predecessor bills, introduced in the 105th Congress, precisely on the basis of the absence of evidence of a problem. ${ }^{196}$ There was significant academic literature, most comprehen-

190. Indeed, in the hearings held in preparation of the predecessor bill 105 H.R. 2652 , an industry representative specifically stated that no instances of such piracy had yet occurred. See CIAA Hearings, supra note 142 (statement of Robert E. Aber, on behalf of the Information Industry Association).

191. Collections of Information Antipiracy Act: Hearing on H.R. 354 Before the Subcomm. on Courts and Intellectual Property of the House Comm. on the Judiciary, 106th Cong., available at 〈http://www.house.gov/judiciary/106-dunc.htm) (testimony of Daniel C. Duncan, Vice President, Government Affairs, Software \& Information Industry Association).

192. See id.

193. See Collections of Information Antipiracy Act: Hearing on H.R. 354 Before the Subcomm. on Courts and Intellectual Property of the House Comm. on the Judiciary, 106th Cong., available at 〈http://www.house.gov/judiciary/106-pete.htm〉 (statement of Marybeth Peters, Register of Copyrights).

194. See H.R. REP. No. 106-350, pt. 1, at 9 (1999).

195. See id. For my discussion of Feist, see infra text accompanying notes 26-32.

196. See CIAA Hearings, supra note 142 (statement of Jonathan Band on behalf of the Online Banking Association); Letter from Pamela Samuelson in response to Tyson/Sherry Report and H.R. 2652, Oct. 23, 1997, available at /http://www.arl.org/info/ frn/copy/psamlet.html). 
sively a 1997 analysis performed by professors Reichman and Samuelson, ${ }^{197}$ explaining why database providers did not in fact need a new right, given the available alternatives for collecting positive returns on their investments without such a right. ${ }^{198}$ Supporters of such a right had ample time to rebut these arguments, but they did not. Indeed, in the testimony of Marilyn Winokur, on behalf of the Coalition Against Database Piracy, all that the witness could do to rebut this criticism was state that "a finding that an industry has done well in the past without legislative protection does not mean that threats to present and future investments fall outside Congressional concern," 199 and that "Congress has no obligation to wait until the harmful ripples created by the gaps in current law become a tidal wave." 200 The lack of data supported only by the weak claim that Congress needs no evidence before it acts strongly suggests that the bill is unnecessary. This is especially true given the serious First Amendment concerns about this law raised by the Administration ${ }^{201}$ and by academic critics $^{202}$ and the resources at the disposal of the supporters of the bill.

The goals of House Bill 1858 are much narrower, though they too are unsupported by evidence of real need, as opposed to real lobbying pressure. The report states as its baseline assumptions the central importance of information flows to efficient markets, and the long standing, "basic information policy of this country ... that facts cannot be 'owned." 203 It expressly states a fundamental commitment to permitting acts that would be rendered illegal by House Bill 354-for example, permitting "a database publisher [to] visit the site of every bank in a State, extract data concerning each bank's loan programs, and construct a larger database with

197. See J. H. Reichman \& Pamela Samuelson, Intellectual Property Rights in Data?, 50 VAND. L. REV. 51 (1997).

198. See id. House Bill 354 itself was criticized on these grounds in Stephen M. Maurer \& Suzanne Scotchmer, Database Protection: Is It Broken and Should We Fix It?, 284 SCIENCE 1129 (1999).

199. See Collections of Information Antipiracy Act: Hearing on H.R. 354 Before the Subcomm. on Courts and Intellectual Property of the House Comm. on the Judiciary, 106th Cong., text accompanying notes 29-30, available at 〈http://www.house.gov/ judiciary/106-wino.htm〉 (summary of statement of Ms. Marilyn Winokur, Executive Vice President of Micromedex, on Behalf of the Coalition Against Database Piracy).

200. See id.

201. See Memorandum from William Michael Treanor, Deputy Assistant Attorney, Office of Legal Counsel July 28, 1998, Constitutional Concerns Raised by the Collections of Information Antipiracy Act, H.R. 2652, available at /http://www.acm.org/ usacm/copyright/doj-hr2652-memo.htmll.

202. See generally sources cited supra notes 1-2.

203. See H.R. REP. No. 106-350, pt. 1, at 8 (1999). 
loan information for all banks." 204 It goes on to say that "[a]nother database publisher can then extract some of that information, and combine it with other information-for example, loan programs from out-of-State banks ... to create a new, more useful database. ... Allowing scientists to reuse facts, rather than requiring them to 'reinvent the wheel,' ensures that research moves forward."205

The report notes that "[w]hile this Nation's non-proprietary information policy serves consumers and industries well, some database publishers are concerned that the current scope of legal protection against unfair competition is insufficient," noting in particular the concern with the state of the law after Feist. ${ }^{206}$ The report responds to this concern by quoting a statistical study that suggested that the commercial database industry has prospered since Feist. ${ }^{207}$ It suggests that between 1991 and 1997, the overall number of databases increased $35 \%$, the number of files contained in these databases increased by $180 \%$, and the number of online searches of databases increased $80 \%$. Furthermore, the database industry has become more, rather than less, commercial, since the 1976 Act clarified the limited extent of protection available to database producers under the Copyright Act, and commercialization has continued apace since Feist, both effects measured by the relative prevalence of commercial, as compared to government, academic, and non-profit database producers. ${ }^{208}$

Despite its very clear rejection of the argument that commercial database producers were suffering under the present legal regime, the report suggests that it is intended to "plug a hole that exists in current law," to give producers "sufficient protection against unfair competition" while avoiding placing "a tax on information" that is necessary for value added publishers, research scientists, or consumers by creating a property-like right. ${ }^{209}$ The report is only slightly more enthusiastic about the second part of the bill, which pertains specifically to real-time market information. It suggests that access to real-time information is very important to online trading, and that the exchanges charge brokers fees to provide them with real time market information, fees that they use to fund their operations. ${ }^{210}$

204. Id.

205. Id.

206. Id. at 9 (emphasis added).

207. See id. at 9 \& n.1 (citing Dr. Martha E. Williams).

208. See H.R. REP. No. 106-350, pt. 1, at 9 (1999).

209. See id. at 10.

210. See Consumer and Investor Access to Information Act: Hearing on H.R.. 1858 Before the Subcomm. on Finance and Hazardous Materials of the House Comm. on Commerce, 106th Cong., available at 〈http://com-notes.house.gov/cchear/ hearings 106.nsf/a317d879d32c08c2852567d300539946/ 
The fear stated in the Report is that consumers or brokers who get access to the information will retransmit the real-time information and undermine the market-information provider's business, and thereby undermine the efficient collection and dissemination of market information. ${ }^{211}$ These fears, as in the case of House Bill 354, were without empirical basis. Indeed, testimony of a staff member of the Securities and Exchange Commission, who supported the bill, specifically stated that the Commission has not completed its analysis of the impact on markets of structural change and the importance of fees-for-information to the operation of markets. ${ }^{212}$ Theoretically, the need for a right in real-time access to information that is generated as a by-product of the market's function, of which the market is a sole source, is questionable. Investments in collecting and organizing the information are necessary for the very functioning of the market, and the marginal cost of providing that information once collected is minimal. It is not entirely clear why these investments-most of which are fixed-cannot adequately be recouped in membership fees or transac-

cd8698843ba70417852567990066c0c1?OpenDocument> (prepared statement of $\mathrm{Mr}$. Richard P. Bernard Executive Vice President and General Counsel New York Stock Exchange, Inc.) (stating that real-time market data fees constituted 15\% of the NYSE's revenues for 1998); Consumer and Investor Access to Information Act: Hearing on H.R.. 1858 Before the Subcomm. on Finance and Hazardous Materials of the House Comm. on Commerce, 106th Cong., available at 〈http://com-notes.house.gov/cchear/ hearings106.nsf/a317d879d32c08c2852567d300539946/

fba0ad30a18737938525679900667a26? OpenDocument) (prepared statement of Mr. S. Dean Furbush, Senior Vice President and Chief Economist, National Association of Securities Dealers, Inc.).

211. See H.R. REP. No. 106-350, pt. 1, at 10-11 (1999).

212. The Securities and Exchange staff member testified as follows:

To address these developing issues, the Commission has undertaken a review of the structures for obtaining market data and the role of data revenues in the operation of the markets. As part of this review, the Commission intends to issue a release describing existing market data fees and revenues, as well as their relationship to the funding of the self-regulatory organizations. While we have gathered a significant amount of data on these subjects, we are just in the preliminary stages of our analyses. Unfortunately, without the benefit of completing this review, we are unable to make judgments on specific issues regarding data collection and distribution costs or on any suggested structural improvements.

Consumer and Investor Access to Information Act: Hearing on H.R.. 1858 Before the Subcomm. on Finance and Hazardous Materials of the House Comm. on Commerce, 106th Cong., available at 〈http://com-notes.house.gov/cchear/hearings 106.nsf/ a317d879d32c08c2852567d300539946/f674ae3a3398544b852567990052238c?

OpenDocument (prepared statement of Ms. Annette L. Nazareth, Director, Division of Market Regulation, Securities and Exchange Commission). 
tional fees, rather than as incremental charges on access to the information. Nonetheless, because the right given is of extremely short duration, fifteen minutes at the most, perhaps less as the speed of markets' response to information increases, it seems that the Committee was content to accept the need for at least this limited right.

\section{Evaluating the Fit Between the Means Employed by the Bills and their Purpose}

As noted earlier, it is not sufficient that a law subject to intermediate scrutiny serves an important purpose: the law must do so without restraining speech much more than necessary. We can assume, for purposes of this part of the inquiry, the counterfactual that there was in fact evidence supporting the claim that database producers are threatened by competitors who use the information contained in their databases as a basis for competing products. ${ }^{213}$ The question is whether one or both of the proposed bills protect database providers from this threat. If both do so, one must ask whether the more restrictive of the two, House Bill 354, is not rendered unconstitutional by the very availability of a plainly less restrictive means-namely, House Bill 1858.

First, the general prohibition in House Bill 354, section 1402(b), on "extraction" that causes material market harm, where "material" means "not de minimis," 214 is certainly one way of making it illegal for competitors to extract information. But it sweeps too broadly. If it is unfair competition that House Bill 354 aims at, then the general prohibition on extraction is unconstitutionally broad, for it would prohibit too many users who are not competitors from reading and communicating facts that they wish to, and can, read and communicate. If the bill in fact aims to prohibit use by users who are not competitors, then the law is not an unfair competition law, but a property right, which cannot be passed outside the Intellectual Property Clause, and is not supported by the committee's own stated purposes.

Second, even section 1402(a) of House Bill 354, which does not limit extraction per se but only "extraction to make available to others," is too broad if it is aimed at unfair competition, not at clarifying property rights in information goods, which is the province of the Intellectual Property Clause. As explained in the preceding section, ${ }^{215}$ while section 102 in House Bill 1858 regulates competitive free-riding, section 1402(a) of House Bill 354 regulates, in addition to that competitive relationship, the

213. The absence of such evidence is described supra Part V.A.

214. See discussion supra Part IV.C.2.

215. See discussion supra Part IV.C. 
division of welfare between present and future information producers. It reaches not only competition among producers of the same product, some of which undercut the others unfairly, but also among producers of different products to the extent that one product is an improvement of, or uses as an input some of, the other product. If in fact the important governmental interest is to prevent undercutting of database producers by competitors who provide the same product without paying the cost of its development, then this section too is unnecessarily broad. It captures and prohibits many forms of valuable communication that "compete" with the original database only in the very limited sense that a public reading of the names of the past year's AIDS victims at a memorial competes with a database collecting public health records from which the list is extracted, or that a list of news tidbits from the passing week in the New York Times Week in Review section competes with the Associated Press newswire.

Third, the exceptions indicate a range of uses that would not fit the "permitted acts" definition, and thus would be prohibited by House Bill 354, and which suggest that House Bill 354 is not narrowly tailored. Section 1403(b) makes amply clear that nonprofit educational, scientific, and research users are prohibited from using information collected by a producer who considers nonprofit educational, scientific, and research users to be its primary market. Recall that "primary market" is not defined in House Bill 354 as the commercial raison d'etre of a database. It includes all markets in which a database is offered and from which the database producer reasonably expects to derive revenue, directly or indirectly. So, imagine a database producer that hits on the business idea to collect and tally information about the voting patterns of legislators throughout the United States, hoping to sell the information to lobbyists. It turns out that this database is a bonanza for political scientists. The producer realizes this, say, after one scientist uses the database, and begins to offer access to this information to political scientists, and "reasonably expects" to charge for such access. The exception in section 1403(b) seems not to apply to any political scientist who thereafter copies the database, runs analyses on the information it incorporates, and publishes the results in a scholarly analysis of the responsiveness of legislatures to, say, petition drives. The researcher's extraction of the information, without payment, seems to fall outside the carve-out for nonprofit research. It is true that the researcher may qualify for the ad hoc balancing exception of section 1403(a), although that possibility is attenuated by the unavailability of the more specific defense. The point, however, is merely to illustrate the kind of valuable speech that would at least be threatened, sometimes prevented, and certainly burdened by House Bill 354. Burdening such speech would have 
nothing to do with providing sufficient incentives for production of the database in the first place, let alone with unfair competition, and would not occur if House Bill 1858, rather than House Bill 354, is adopted.

Under House Bill 1858, the political scientist's initial act of extracting the information would not be captured by the prohibition to begin with. Moreover, under House Bill 1858's parallel exception, a nonprofit scientific, educational, or research user is privileged even to distribute or sell a duplicate, unless that distribution is "part of a consistent pattern engaged in for the purposes of competition" with the producer of the database. ${ }^{216}$ So copying and distribution to students of data in a database that a teacher thinks would be useful in the classroom is privileged; only systematic duplication and distribution in competition with the producer would come under the act as envisioned in House Bill 1858.

House Bill 1858 is designed to capture a very narrow set of practices: duplication and sale in competition. The bill's definition of "duplicate" excludes copying into a second database if other materials in that second database are material to its value. This narrow definition alleviates many of the concerns raised in the preceding paragraphs about the broad reach of House Bill 354. The bill deals narrowly with the problem of undercutting competitors by relying on their investments. The primary question with respect to it, therefore, appears to be the absence of any serious justification of its purpose, other than the Committee Reports' intimation that the database producers lobbied hard, ${ }^{217}$ rather than any concerns about the breadth of the net it casts in aid of that purpose.

\section{Conclusion}

Both database protection bills are regulations on information use and exchange. Both are thus regulations of speech, in the sense that they are subject to First Amendment scrutiny. For the most part, they are both content-neutral, and should be treated as functionally equivalent to structural media regulations-i.e., laws that regulate information production and exchange with the intent of improving information flows, but do so by regulating how people can and cannot, produce, use, and exchange information. These laws are subject to an intermediate level of scrutiny, most plainly stated in Turner $I^{218}$ They must be shown to be aimed at an important government interest, to be capable of actually serving that goal, and

216. H.R. 1858, 106th Cong. § 103(d) (1999).

217. See H.R. REP. No. 106-350, at 10 ("[T] thorized commercial copying of databases, particularly comprehensive databases stored in digital form, may sometimes go unremedied because of gaps in current law.").

218. See Turner Broad. Sys., Inc. v. FCC, 512 U.S. 622 (1994). 
not to serve that goal in a manner that is much more restrictive of speech than necessary.

House Bill 354 fails this level of intermediate scrutiny both because there is no basis to believe that the important government interest claimed by its drafters really exists, and because even if there were such basis, it regulates speech much more broadly than necessary to attain its stated goal. No serious evidence was presented to Congress or identified by the committee that the database industry in fact needs any new protection. Evidence identified in the Committee Report for House Bill 1858 specifically refutes the claim that there is a need for something like a property right in raw information in databases-whether it is called a sui generis property right or a robust unfair competition rule. The database industry, and in particular its commercial component, have grown robustly both before and after Feist. Short of generalized statements of the possibility of "piracy" there was no evidence to suggest that widespread consumer or competitor practices undercut the ability of commercial database producers to support their continued investment in the production, maintenance, and distribution of databases.

Moreover, despite this lack of evidence, House Bill 354 sweeps much more broadly than necessary given those justifications offered-if not supported-by the Committee Report on the bill. Its general prohibition on extraction, its broad definitions of primary and related markets, the sweep of productive uses it captures for the benefit of existing database owners at the expense of future database producers and their consumers, and the property-like protection (in terms of the economic function of the rights created) it provides for the information contained in databases simply cover too many ways in which people want to and can use information in databases. It prohibits or burdens with uncertainty too many valuable uses of information, both commercial and noncommercial, both amateur and professional, which do not compete with, and certainly do not undercut, commercial database producers. In the absence of serious evidence that the database industry is broken, it imposes this heavy burden for highly speculative a gain.

House Bill 1858 is similarly thin on evidence that there is a real need for a new right. Authors of the Committee Report on that bill do little to support that claim, other than begrudgingly admit that database providers sought some protection, and this seems to have been the minimal protection that would do to ameliorate the pressure whose primary product is House Bill 354. Even with respect to its second section, which creates something like a fifteen minute property right in real-time market information, most of the testimony that supported the bill came from online bro- 
kers who sought greater access to the information, ${ }^{219}$ while those who testified to a market need for such a right in fact supported the much broader rights created in House Bill $354{ }^{220}$ Nonetheless, the narrowness of the prohibitions created in House Bill 1858, on both its parts and its placing of enforcement responsibility with the Federal Trade Commission, thereby limiting the risk of anticompetitive abuses of the prohibition by database owners, suggest that the harm that would be imposed by this bill, if passed, would be relatively minimal.

\section{CONCLUSION}

The United States Constitution imposes two constraints on Congress's power to regulate information production and exchange by creating and enforcing private rights. First, the Intellectual Property Clause requires that all rights that function as exclusive, property-like rights be passed under that clause, and within its constraints. Under the Intellectual Property Clause, Congress may create such rights if and when they are likely to encourage information production more than they inhibit it. Moreover, these rights must be available only to those who make original contributions to the wealth of our collective knowledge, and the exclusive right enacted should not remove from, or burden free access to, information already in the public domain. Because Congress's power to enact such property-like rights is substantively limited in this way, Congress may not pass functionally equivalent rights under any other power, including the commerce power, unless these rights too comply with the limitations imposed by the Intellectual Property Clause. If it is to regulate markets in information by creating private rights that do not comply with these basic limitations, it can only do so if these rights are different in kind than intellectual property rights.

Whether private rights in information markets are created within or without the Intellectual Property Clause, and even if they either comply with the requirements of that clause or are exempt from it because properly enacted under another power, all such private rights are subject to

219. See Consumer and Investor Access to Information Act: Hearing on H.R. 1858 Before the Subcomm. on Finance and Hazardous Materials of the House Comm. on Commerce, 106th Cong., available at 〈http://com-notes.house.gov/cchear/ hearings 106.nsf/768df0faa6d9ddab852564f1004886c0/

$7 \mathrm{cfb} 78 \mathrm{eed} 9$ dab88e852567cf0047a7a8?OpenDocument) (including testimony from representatives of Bloomberg Financial Markets, New York Stock Exchange, Charles Schwab and Company, National Association of Securities Dealers, DLJdirect, Securities and Exchange Commission, and Ameritrade Holding Corporation).

220. See id. 
First Amendment review. All such rights, even if intended to aid the efficient production of information, entail prohibiting some people from accessing information or communicating it in certain ways that they can and wish to. They must all therefore pass at least the intermediate level of First Amendment scrutiny courts apply to the most closely analogous form of information market regulation-structural media regulation. To be valid, such rights must be shown to advance an important, noncensorial government purpose, and must do so without burdening more speech than necessary.

The reason for the robust judicial review created by these cumulative constraints on congressional power has to do with the importance of information to our society and with the systematic biases of the political economy of enclosure. The capacity to access information, to rework it, and to communicate it to others in society is central both to political selfgovernance and to personal autonomy. Laws that constrain access to information or limit the ways in which individuals of communities of interest can shape their information environment should be subject to the same careful judicial protection that has traditionally led courts to protect these values. Furthermore, legislation that encloses the public domain is systematically subject to biased presentation of its social costs and benefits. Owners of information goods usually see the social benefits of new enclosure legislation as private benefits that can be captured by enforcement of the proposed new property rights. They can fully present these benefits to the legislature. The social costs of such new rights, however, are widely dispersed and external to most users who will over time experience them. In particular, intellectual property rights systematically benefit present generations of producers over future generations of producers, who are often entirely absent from the debate when legislation whose price they will be required to pay is considered. The legislative process is therefore systematically biased in the direction of overprotection. Courts, presented as they are with disputes between similarly engaged parties, are in a better position, over time, to perceive the social costs of enclosure. The robust system of judicial review gives them an opportunity to use this informational advantage to provide a counterbalance to the legislative bias on such a central aspect of our social welfare-information production and dissemination.

The more expansive of the two proposed database protection bills currently before Congress, House Bill 354, fails both constitutional tests. Despite protestations to the contrary, a functional analysis of its provisions suggests that it creates a set of rights much more analogous to intellectual property rights than to unfair competition rules enforceable by a private 
right of action. The bill creates rights to exclude users of the information for its intended use, as well as competitors. It tracks rights in a collection through successive, non-duplicative productive uses, and secures for the producers of databases a return on their investment's contributions to other, downstream producers. In all these attributes the bill functions like an intellectual property right. Its exemptions and exclusions do not affect this basic function, but merely outline its contours. As an intellectualproperty-like right, the bill must be passed, if at all, under the Intellectual Property Clause. However, the Supreme Court's decision in Feist prevents protection of raw data in compilations by an intellectual-property like right. Congress's attempt to pass such a right under the Commerce Clause is invalid, as is therefore the proposed statute.

Similarly, even if this bill were not invalid under the Intellectual Property Clause, it would be invalid under the First Amendment. No evidence was presented in Congress to suggest that database producers in fact required any protection at all. In particular, the Committee Report focused on the fear of certain sharp competitive practices, but provided no plausible basis to think that the database industry is threatened by inability to exclude users from databases, or by inability of database producers to capture the entire value that their investment in collecting information provides to subsequent database producers. The breadth of the bill's prohibitions and its capacity to reach many valuable uses and exchanges of factual information suggest that the bill restricts speech too extensively in pursuit of too speculative a gain. This factor is emphasized by the likely efficacy of the alternative bill, House Bill 1858, to attain the core concerns regarding free riding and ruinous competition.

House Bill 1858 does in fact create a competition regulation regime, not a property-like entitlement in database producers. It addresses only competitors, and only a certain subset of competitors, namely those who sell near-identical databases to the database from which they extracted the information. It prohibits only sale in competition with the source from which the duplicative database was duplicated. It does not speak to consumers. It does not speak to producers of other databases who add their own information to information they collect from databases produced by others, whether these value-added databases compete with their source or not. These limitations narrow the focus of House Bill 1858 such that it is plainly not a part of the basic definition of the economic excludability of information contained in databases. It is a regulation of a particular form of competition deemed ruinous and nonproductive. As such, House Bill 1858 can properly be passed under the Commerce Clause without reference to the limitations of the Intellectual Property Clause, and its protec- 
tion for raw data, unattainable under the Intellectual Property Clause itself, is constitutionally permissible.

As was the case with House Bill 354, evidence that House Bill 1858 is necessary to serve the important governmental interest in the growth and development of a robust database industry is lacking. The Committee Report seems to suggest only that Congress was subject to pressure from the database industry, not that it was persuaded that something was fundamentally wrong that needed to be fixed before this industry could flourish. Indeed, the report directly cites evidence to suggest that there is no problem. Nonetheless, the bill's prohibitions on use of information are so narrow that despite the limited evidence that it serves an important governmental interest, it may be an appropriate regulation of speech, at least as a general matter, barring a specific context of application where it should no longer be seen as such.

The two bills nicely exemplify the way in which the constitutional constraints on Congress's power to create private rights in information and information goods interact. They suggest a cumulative effect, with the Intellectual Property Clause functioning as a threshold constraint on Congress's power to enact such rights, and the First Amendment overlaying a more context specific judicial evaluation of such rights, whether or not they pass muster under the threshold constraint. 
BERKELEY TECHNOLOGY LAW JOURNAL 